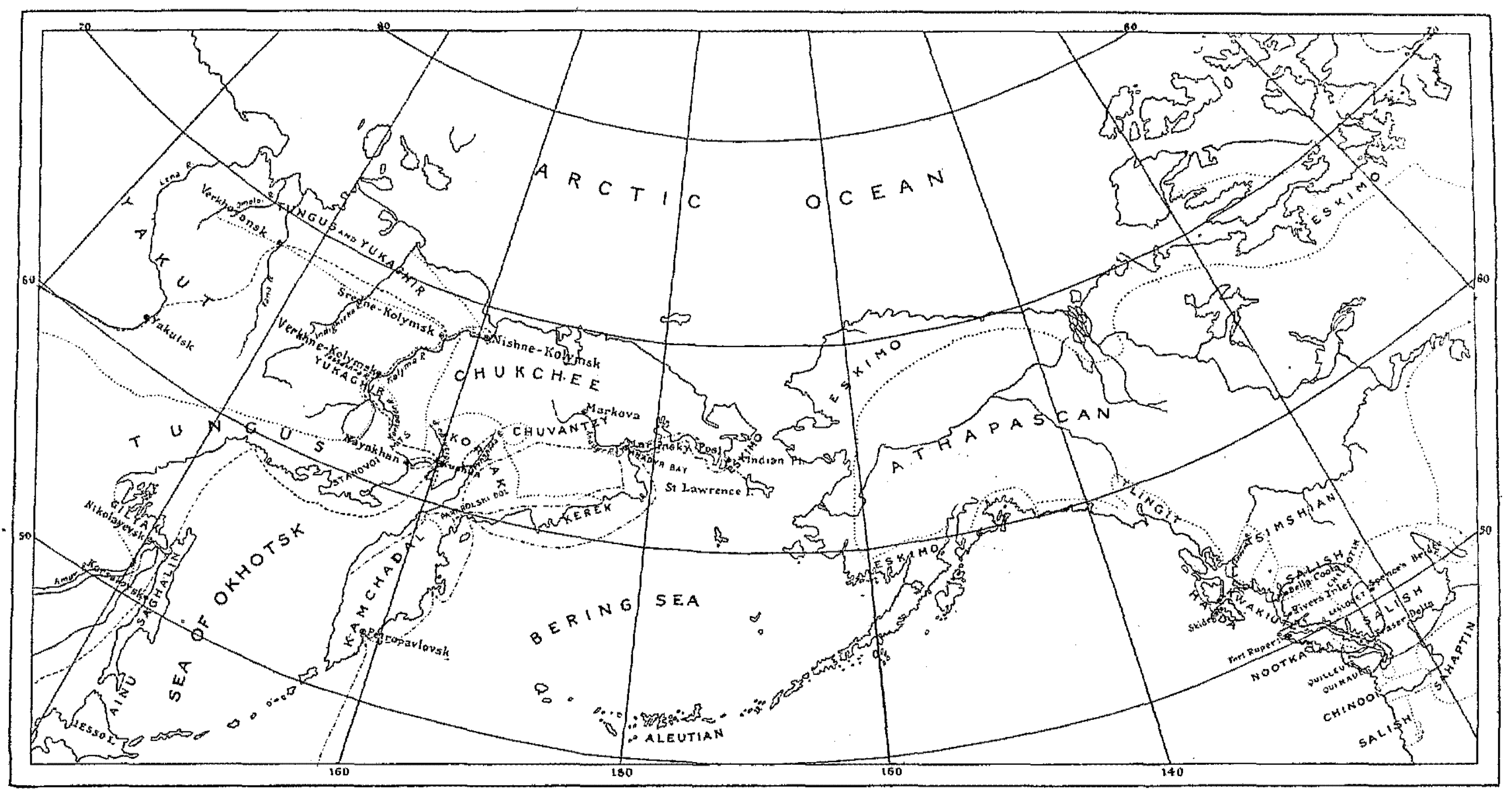

ROUTE-MAP, JESUP NORTH PACIFIC EXPEDITION

The red lines show the principal routes traversed by the parties in the field from IS97 to Igoz inclusive. In North America the journeys of the different parties have not been indicated separately, the country having been covered in so many directions: in Asia the dot-and-dash line shows the course followed by the Bogoras party; the broken line, that of the Jochelson party; the solid line, that of the Laufer party. 


\section{THE AMERICAN MUSEUM JOURNAL}

\section{THE JESUP NORTH PACIFIC EXPEDITION.}

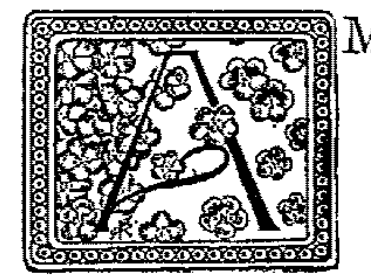

MONG the great problems of anthropology, the one which stands out as of particular interest and importance to the American people is the problem of the earliest history of the native races of our continent and their relation to the races of the Old World. Questions relating to this problem have been the subject of much spectlation, particularly in our own country. While the science of anthropology was still in its infancy, the flight of imagination carried away investigators and led them to identify the American race with one or another ancient people of the Old World. Later a reaction set in, which culminated in the view of Dr. D. G. Brinton, who considered the American race and American culture as entirely independent of those of the Old World. This view, however, seems to be too extreme to be tenable. The question of the relation between the people of the Old World and those of the New may be stated in the following manner:

There is little doubt that the American race has inhabited our continent for a long time. Although no finds have been made that establish its geological antiquity beyond cavil, we have good reason to believe that man inhabited this continent at a very early time. The principal foundation for this belief is the existence of well-marked varieties of the American race, the establishment of which must have occupied a long period. The general characteristics of the race are fairly uniform. The smooth dark. hair, broad heavy face, large nose and rather full mouth are common to all the natives of America. But nevertheless a number of distinct types have developed, differing in color of skin, in form of head and of face and in proportions of the body. The differences in these types show that much time was necessary for their development.

The long occupancy of our continent, which thus seems. probable, implies that American culture passed through a longperiod of development. It is likely that the distinct types of the race developed in isolated spots, and therefore culture must also have followed distinct lines of growth. 


\section{THE AMERICAN MUSEUM JOURNAL}

'This period, however, has long since passed. At the time when American tribes entered the field of our knowledge, and even in periods of which archrology alone gives evidence, contact had been established between the tribes of the north and of the south, of the east and of the west, so that it is no longer possible to consider as the product of isolation the cultural possessions of each tribe. Archæological evidence also shows that distinct types followed one another in the occupancy of each area. In short, changes of far-reaching importance took place long before the tribes became known to history. These changes imply mixture of blood as well as exchange of cultural achievement.

A systematic investigation of the question in how far American race and culture can be considered as independent must necessarily take up the study of those regions where the geographical connection between the O1d World and the New is closest. One of these regions is the coast of the North Pacific Ocean; another is far to the south, where the wide scattering of the Polynesian people suggests the possibility that they also may have reached our continent. Of these two regions the northern one seemed to be more likely to give results. Here the geographical conditions favor migration along the coast-line and exchange of culture. Our knowledge of this area previous to the work of the Jesup Expedition indicated that manifold changes in the culture and location of the tribes inhabiting this area had taken place. The multiplicity of languages spoken along both coasts, and their division into numerous dialects; the great variety of types of the area, their irregular distribution and their affiliations with types of distant regions; the pectliar types of culture,-all indicate that the primitive tribes of the coast have passed through a long and varied history. The types of man which we find on the North Pacific coast of America, while distinctly American, show a great affinity to North Asiatic forms, and the question arises, whether this affinity is due to mixture, to migration or to gradual differentiation. The culture of the area shows many traits that suggest a common origin, and others that indicate diverse lines of development.

What relation these tribes bear to each other, and particularly 


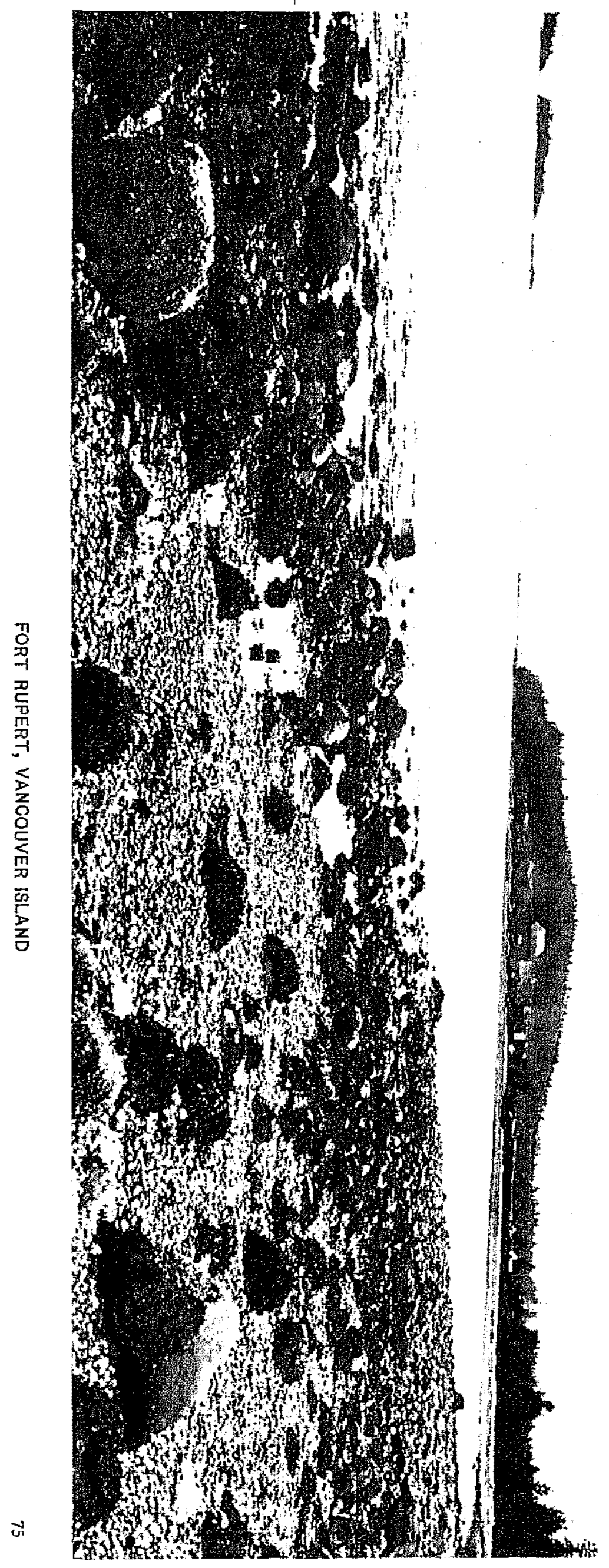




\section{THE AMERICAN MUSEUM JOURNAL}

what influence the inhabitants of one continent may have exerted on those of the other, are problems of great magnitude, the solution of which lies in a careful study of the natives of the coast, past and present, with a view to discovering as much as possible of their history. These were the problems that attracted the attention of Morris K. Jesup, Esq., President of the American Museum of Natural History, and induced him to provide personally with great liberality the means for carrying on investigations.

Since the ultimate conclusions of the expedition were to be based on detailed comparisons of the types of man, cultures and languages of the North Pacific coast, it was necessary to organize several expeditions to collect the required information. It seemed best to divide the area among specialists, each devoting his energies to a certain group of tribes. The amount of work to be done in both Siberia and America was very great, on account of the great differentiation of tribes. It therefore seemed necessary to set certain limits to the work of the expedition. In Asia the isolated tribes of northeastern Siberia were made the special subject of our studies, while in America the isolated tribes between Bering Strait and Columbia River were to be investigated. The problem to be solved in Asia was the relation of the isolated tribes of Siberia to the Turkish and Tungus tribes of that continent on the one hand, and to the isolated tribes of northwestern America on the other. In a similar way the problem in America was the relation of the coast tribes of the Northwest to the inland and southern tribes of our continent and to the Siberian tribes of the other.

The multiplicity of tribes in America is clearly shown on the map on page 68. Since the Eskimo of Alaska had been studied by Mr. E. W. Nelson for the United States Government, and since the Tlingit had been investigated by Lieut. G. T. Emmons, U. S. N., who it is hoped may publish the results of his researches, the principal work by the Jesup Expedition had to be done in British Columbia and the State of Washington. The most important topics to be studied were the eth- 


\section{THE AMERICAN MUSEUM JOURNAL}

nology of the coast of Washington, that of the Salish tribes of the interior and of the coast, that of the tribes of Vancouver Island and that of the Haida of Queen Charlotte Islands. At the same time archæological investigations had to be carried on in the whole region.

The party which carried on operations during the year I 897 consisted of Prof. Franz Boas of the American Museum of Natural History, Prof. Livingston Farrand of Columbia University, New York, and Mr. Harlan I. Smith of the American Museum of Natural History. This party was assisted in the field by Mr. James Teit of Spence's Bridge, B. C., Mr. George Hunt of Fort Rupert, B.C., and Mr. Fillip Jacobsen of Clayoquot, B. C. The New York party travelled westward by way of the Northern Pacific railroad, through the courtesy of whose officials the journey was rendered most pleasant. After having made the necessary preparations in Victoria, B. C., they proceeded to Spence's Bridge, where they arrived on the $2 \mathrm{~d}$ of June, and were met there by Mr. Teit. The great familiarity with the language of this area which Mr. Teit had acquired during a long period of residence there, and the deep interest which he took in the Indians, made him a most valuable assistant in the investigations. Early in the year 1897 he collected notes on the Thompson River Indians for the use of the Jesup Expedition; and with his help a number of additional data were obtained, mainly bearing upon the art of the Indians, their language and their physical characteristics. While these investigations were being carried on, Mr. Smith made preparations for archrological investigations in the valley of the Thompson River.

It was soon found that Spence's Bridge was not the most favorable place for excavations; and for this reason Mr. Smith moved his base of operations, first to Kamloops and later to Lytton, which is situated at the confluence of the Fraser and Thompson Rivers. At Kamloops and Lytton, Mr. Smith conducted extensive excavations on the hillsides and in the valley, discovering numerous remains of previous habitations, some of which are without doubt of considerable antiquity. Almost all 


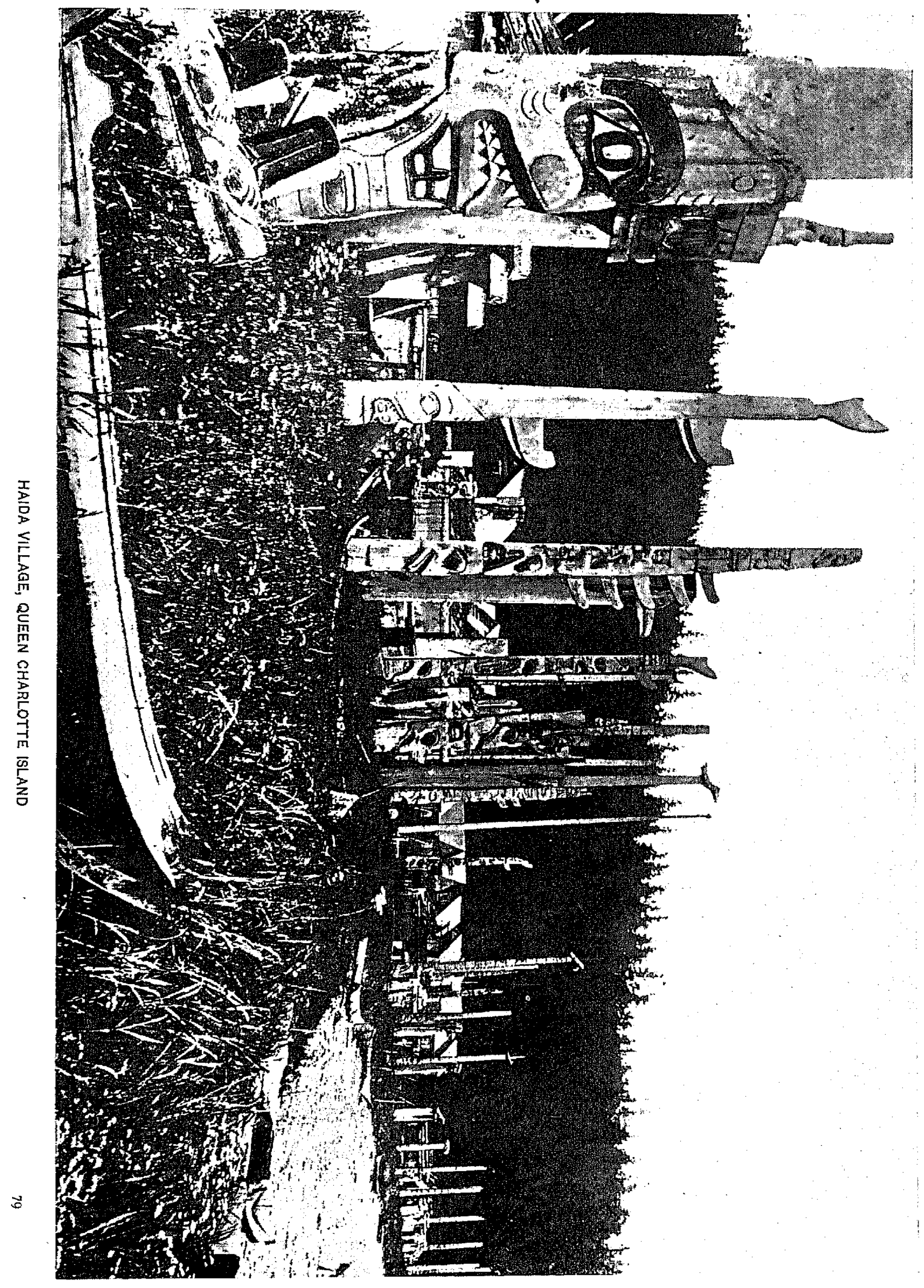




\section{THE AMERICAN MUSEUM JOURNAL}

his finds antedate the advent of the whites and give us an excellent insight into the culture of the people at that period. Beautiful carvings in bone illustrate the high development of plastic art that had been attained by the Indians; shells from the seacoast indicate the existence of early intertribal trade, and numerous implements made of stone, bone and shell illustrate the general state of culture of the tribe.

While Mr. Smith was conducting his investigations at Kamloops, Professors Boas and Farrand, accompanied by Mr. Teit, started on a lengthy trip northward, which was intended to serve two purposes: to investigate the physical characteristics of the Indians inhabiting the banks of the Fraser River north of Lytton, and to study the customs and physical characteristics of the Chilcotin, the most southern Athapascan tribe of British Columbia. From Chilcotin it was intended to continue the journey over the mountains to the coast, in order to study the Bella Coola, an interesting tribe, whose customs and beliefs had never been subjected to systematic inquiry. The party started with a train of ten horses from Spence's Bridge and crossed the mountains to Lillooet on narrow trails. It was hoped that a considerable number of Indians would be met with in the high valley of Botani, where the tribes of Fraser River and Thompson River assemble every spring, but only comparatively few were encountered and the journey was continued after a short delay.

At Lillooet Professor Farrand separated from the main party and visited the villages of the Upper Lillooet on Seton and Anderson Lakes. Meanwhile the pack-train slowly proceeded along the wagon-road leading to Caribou. All the Indian villages that are situated on or near the wagon-road were visited, and a considerable number of anthropometric measurements were col1ected. After about a week Professor Farrand, who had completed his work among the Lillooet tribe, rejoined the party. On the 3d of July they reached Soda Creek, on Fraser River, the most northern village inhabited by the Shuswap tribe. Then they crossed the river and proceeded westward in order to visit the territory of the Chilcotin. After a few days the first village of this tribe was reached. The party proceeded slowly from 


\section{THE AMERICAN MUSEUM JOURNAL}

village to village until the most western Chilcotin village of any considerable size was reached. Now the further investigation of the interesting tribe was left to Professor Farrand, while Professor Boas proceeded on his joumey across the mountains to Bella Coola.

The Chilcotin have been brought into contact with the whites in comparatively recent tine, and, although they now live in log-cabins, raise cattle and horses, and till the soil, they are probably the most primitive among the tribes of British Columbia. A number of families still roam in the mountains between Lillooet and Chilcotin River, and have not been induced to settle on reservations; consequently the field of investigation was most interesting, and the results of Professor Farrand's ethnological inquiries are of great value. He spent most of his time in the larger villages of the Chilcotin; but during the month. of August he visited the isolated families which live on the shores of Tatla Lake and in the mountains. From here he proceeded northward until the pass which leads to Bella Coola was reached.

Professor Boas followed the more northern route towards this pass, crossing the wild plateat north of Tatla Lake. On this journey a few of the Chilcotin who make their home near Lake Nakoontloon were encountered. From here there seems to be an enormous gap in the Coast Range, through which a trail leads westward, following a small river that takes its rise in the high mountains of the range. Gradually the valley narrows and the beatiful peaks and glaciers of the Coast Range come into view. The trail ascends higher and higher, until at a height of five thousand feet the summit is reached. Here a few small snow-fields have to be crossed and the trail suddenly emerges on the north side of Bella Coola River. The river is visible almost five thousand feet below; and on the opposite side of its deep and narrow valley rises the high peak, Nuskulst, which plays a most important part in the mythology of the Bella Coola. Enormous glaciers flank the sides of the mountain. A little farther down the river other snow-clad mountains of beatitiful form come into view. In early times the villages of the Bella Coola were found all along the river, up to a place about twenty miles above 


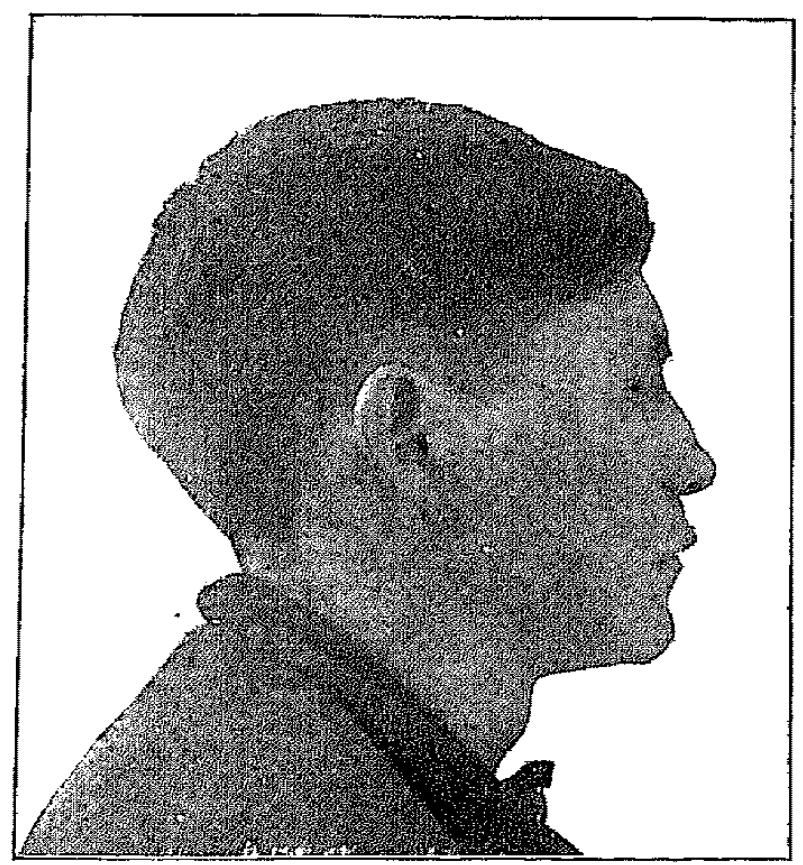

TSIMSHIAN

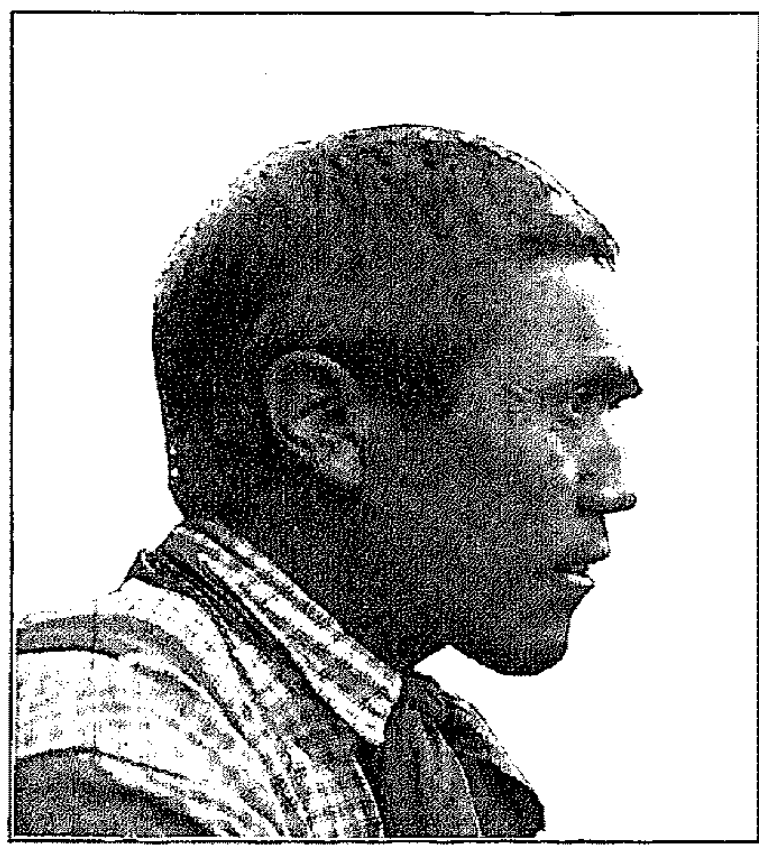

KWAKIUTL

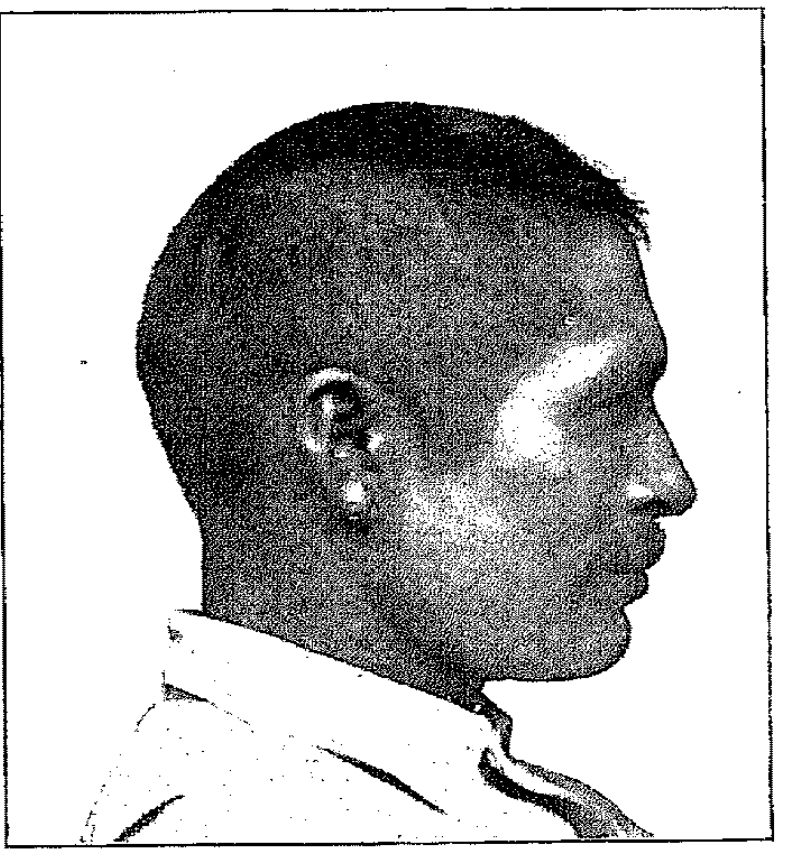

THOMPSON

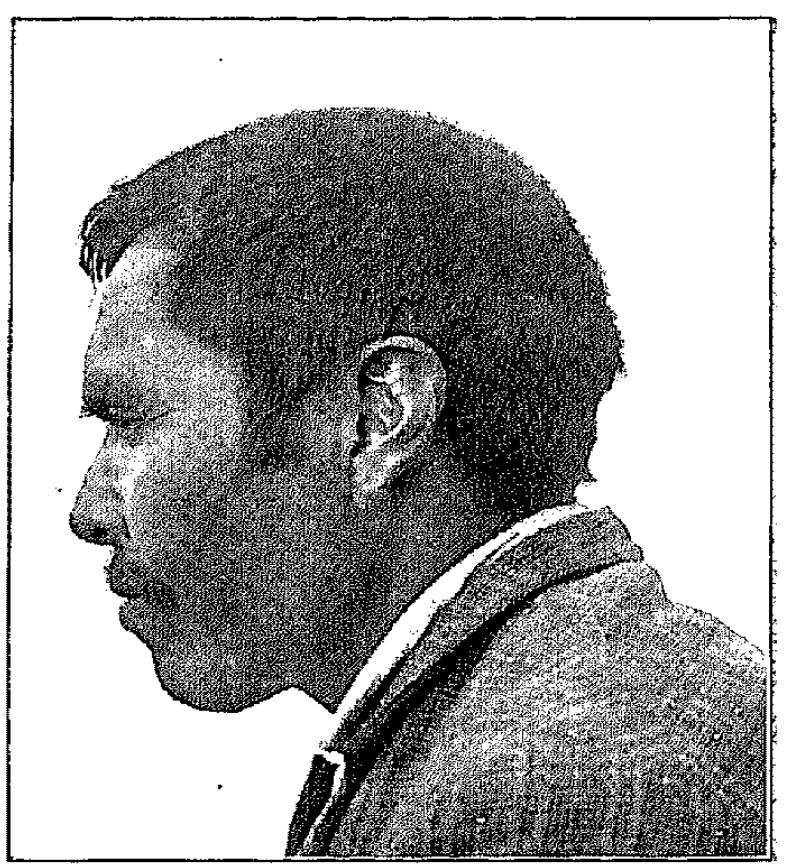

HAIDA

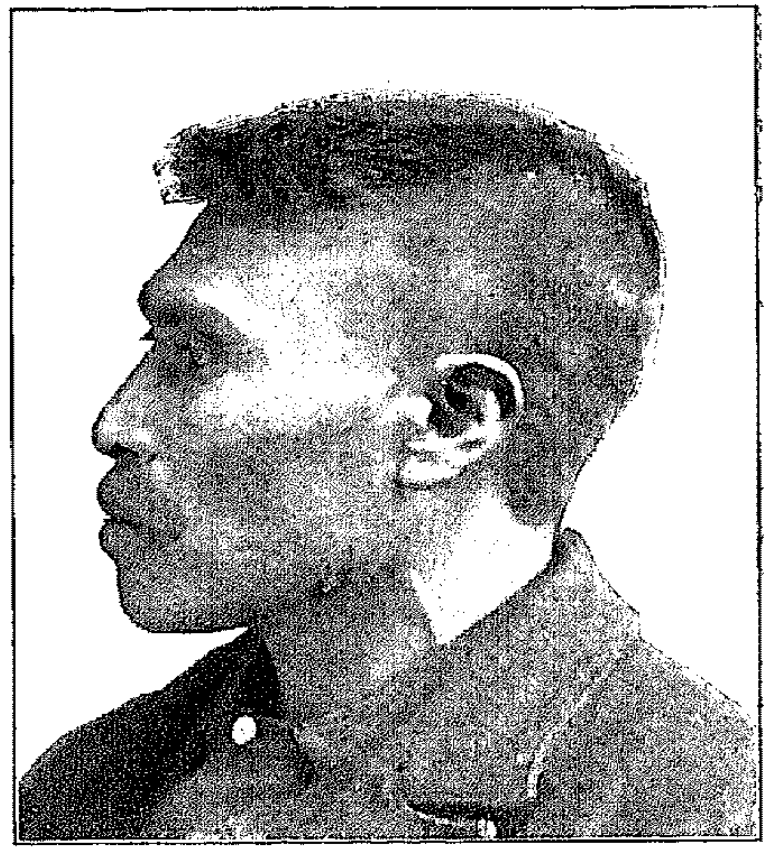

MOOTKA

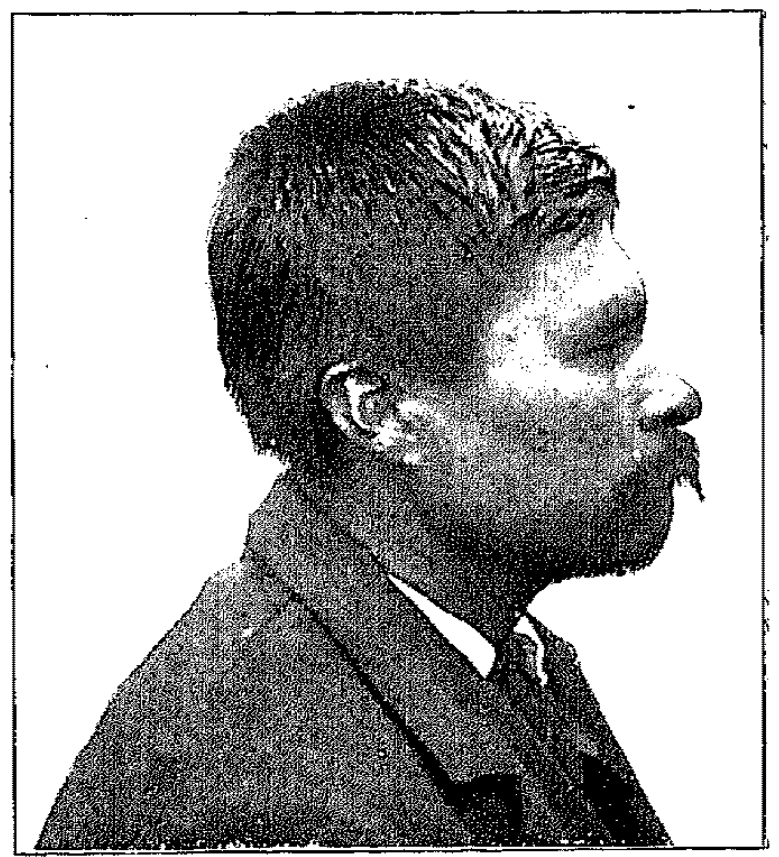

QUINAULT 


\section{THE AMERICAN MUSEUM JOURNAL}

Nuskulst, but the tribe has so diminished in numbers that all the villages on the banks of the river have been abandoned. The trail clescends the steep mountain-side until the river is reached, at a point about twenty-five miles above its mouth. Here the deep and rapid river had to be crossed. The party built a raft, on which an Indian embarked in order to fetch a canoe that was seen on the other side. In this the men crossed the river, while the horses swam over. Another day's journey brought the travellers to the village of the Bella Coola Indians. The road passes through a Norwegian settlement that has recently been established in this valley. At Bella Coola Professor Boas was met by Mr. Hunt, who, under special instructions, had collected valuable specimens among the Indians. The pack-train returned over the mountains to Fraser River, while Professor Boas staid among the Bella Coola Indians.

After obtaining much interesting information regarding the customs and beliefs of the Bella Coola, Professor Boas started down Bentinck Arm. Then he went by steamer northward to Skeena River, where he joined Mr. Smith, who had finished his work in the interior of British Columbia by the beginning of August. Some time was spent near the mouth of Skeena River in making investigations on the graphic art of the Haida Indians and in studying the physical appearance of the Tsimshian and Haida. Mr. Smith obtained a valuable series of photographs, while Professor Boas was engaged in making measurements of the people. By this time Professor Farrand had completed his work among the Chilcotin. Accompanied by an Indian, he crossed the mountains and at Bella Coola met Mr. Hunt, who was finishing his work in that tribe. Toward the end of August, both left Bella Coola to pay a visit to the village of Bella Bella, which is situated just outside the mouth of Bentinck Arm. Professor Farrand spent the remainder of the summer here studying the social organization and arts of this tribe, and Mr. Smith assisted him in the study of the physical appearance of the people.

After Professor Boas had completed his work on Skeena River, he journeyed southward on a coast steamer and was joined at Bella Bella by Mr. Smith and Mr. Hunt, while Professor 


\section{THE AMERICAN MUSEUM JOURNAL}

Farrand staid behind, continuing his investigations. The party landed in Rivers Inlet, where a stay of several weeks was made. Mr. Smith again assisted in the study of the physical appearance of the Indians, and after this work had been ended continued his journey to Vancouver, in order to resume his archaological investigations. Professor Boas and Mr. Hunt, who staid at Rivers Inlet, succeeded in collecting much interesting material on the language and customs of this little-known tribe. In the middle of September Professor Farrand joined them, having completed his work at Bella Bella. Soon afterward Mr. Hunt went to his home in Fort Rupert, while Professors Boas and Farrand returned to New York.

Mr. Smith, after going back to Vancouver, took up the investigation of the shell mounds at the mouth of Fraser River, which yielded important results, clearing up interesting points in the history of the Indians. It seems that the physical appearance of the Indians during the period of deposit of the shell mounds on Lower Fraser River had undergone material changes. The results that were obtained here were so important that it was necessary to continue the researches during the next year. When the rainy season set in, Mr. Smith moved his camp to southeastern Vancouver Island, where he spent some time in the investigation of prehistoric stone monuments. Finally, in the middle of November, the winter rains set in, which compelled him to conclude his operations.

During the summer Mr. Fillip Jacobsen undertook to make a collection illustrating the culture of the tribes of the west coast of Vancouver Island. His intimate acquaintance with the Indians and his varied experience in ethnological work made his assistance of great value. The expedition is also under great obligations to Dr. Charles $F$. Newcombe, who contributed an interesting collection from Queen Charlotte Islands.

In the summer of 1898 work in the State of Washington was begun by Professor Farrand and Mr. Smith. The isolated character of the coast-line between Grey's Harbor and Cape Flattery had subjected the Indians who inhabit it to less white influence than most of the Pacific tribes, and rendered their investiga- 


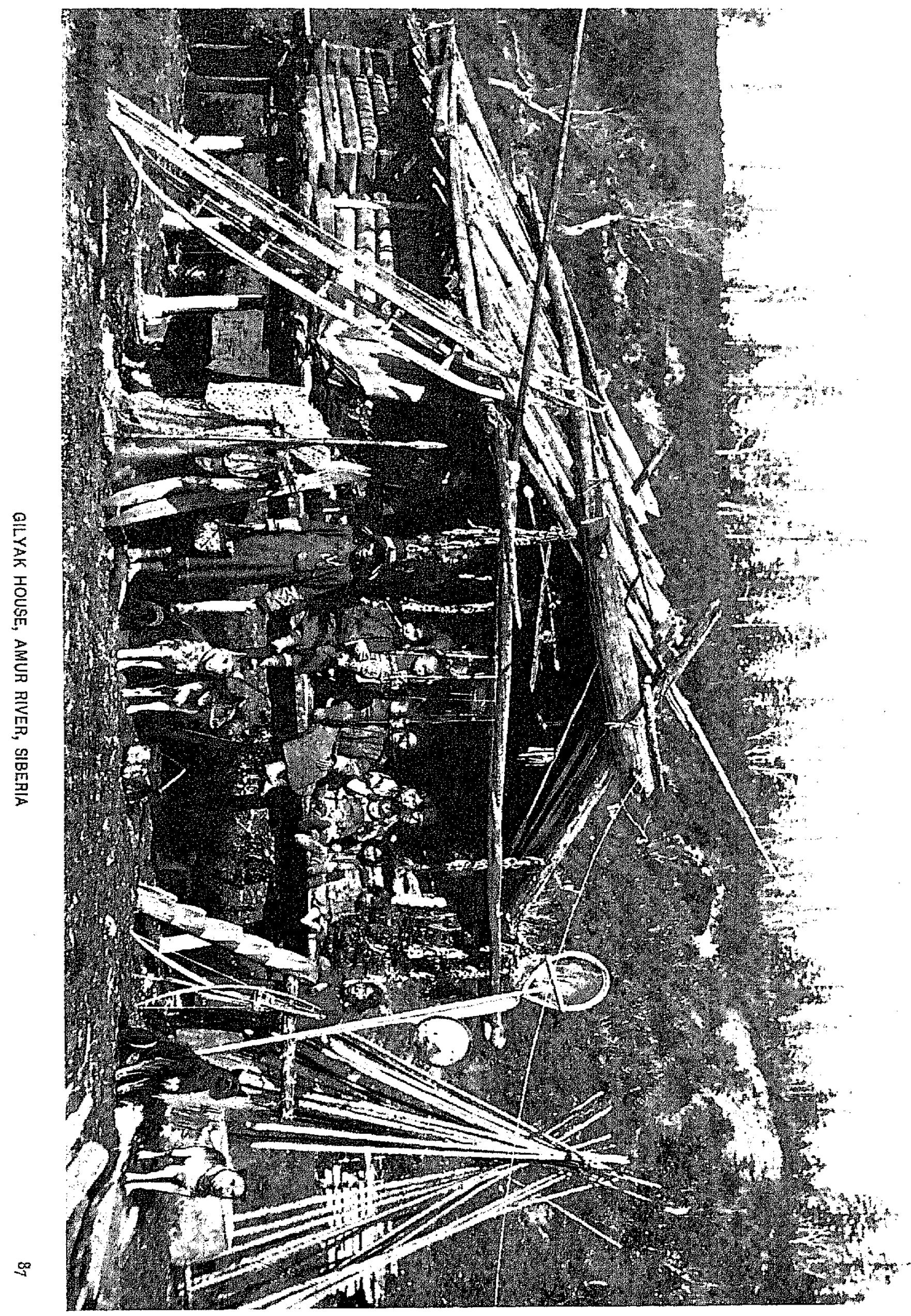




\section{THE AMERICAN MUSEUM JOURNAL}

tion of particular interest. The region also formed a geographical link between the Vancouver Island and British Columbia stocks on the north and the Chinook on the south, both of which had previously been visited and studied, and had disclosed a number of problems with reference to the sultural relations between them which demanded the filling out of the gap. The territory in question is occupied by two tribes - the Quilleute on the north and the Quinault on the south; the former now the sole representative of the Chimakuan stock, and the latter one of the southern representatives of the Salish group. Professor Farrand first visited the Quilleute, reaching their village by way of the Strait of Juan de Fuca and an overland trail from Clallam to Lapush on the coast. Unfortunately, he found upon his arrival that almost the entire tribe had scattered for the summer salmon-fisheries, and it was impossible to procure the casts and records which were desired, but he remained for some days collecting such information regarding customs and folk-lore as was possible and preparing for a second visit later in. the season. He then pushed on to the Quinault, where he had been preceded by Dr. Roland B. Dixon, who had been occupied in making casts of those Indians, and who, shortly after Professor Farrand's arrival, proceeded to the mouth of Fraser River to. carry on his work there. Professor Farrand remained at the Quinault agency for nearly two months, engaged in making general ethnological and linguistic observations, and met with gratifying success. Toward the end of the summer he returned to the Quilleute, and, while still unable to find more than a few individuals of the tribe, collected some linguistic and other ethnological material of interest. The general results of the work show very clearly the gradual merging of the culture of the Northwest into the more southerly type. This merging is particularly observable in the mythology of the tribes.

In the summer of $1898 \mathrm{Mr}$. James Teit paid a prolonged visit to the Lillooet tribe, which is located in the mountains north of the Fraser River delta. He entered the territory of the tribe from the north and visited all their villages. The Lillooet were found to be of particular interest, because they form a link be- 


\section{THE AMERICAN MUSEUM' JOURNAL}

tween the coast tribes and those of the interior. Dr. Dixon and Mr. Smith entered the Lillooet territory at the same time from the south. On this trip Dr. Dixon collected a number of photographs and plaster casts illustrating the types of this region, while Mr. Smith made a number of excavations at ancient village sites. In the same year Mr. George Funt continued his collections among the Kwakiutl of Vancouver Island, a tribe with whose language he is thoroughly familiar.

Mr. Smith spent the greater part of the summer excavating in the shell mounds of Puget Sound and of the west coast of Washington. The results of his excavations show that there was a gradual merging of the ancient culture of this area into that of the Columbia valley, thus agreeing with the ethnological results obtained by Professor Farrand. Archæological work in this area requires much time and persistence, on account of the great scarcity of specimens in the shell mounds. On his return journey Mr. Smith investigated the Indian remains sotth of Spence's Bridge, and here also a gradual change of culture seemed to be revealed.

In 1899 the principal operations of the expedition were in Asia, as will be described later on; but Messrs. Hunt, Teit and Smith continued their researches. Mr. Smith turned his attention to the shell mounds and burial-cairns of northern Vancouver Island and the islands off the coast of Washington. Many of these cairns were explored, and the shell-heaps near which they were usually placed were examined. The cairns were found invariably to be of great age, and the skeletons which they contained were in a bad state of preservation, but much interesting information regarding the methods of burial of the prehistoric occupants of the region was brought to light, and much material for a study of their physical characteristics was obtained. Mr. Smith's work is the first comprehensive survey of the archeology of this region which has been made.

In I900 Mr. Teit continued his work on the Salish tribes of the interior of British Columbia. Professor Boas first joined Mr. Teit, and undertook with him a journey on horseback to the villages of the Thompson Indians south of Spence's Bridge. 


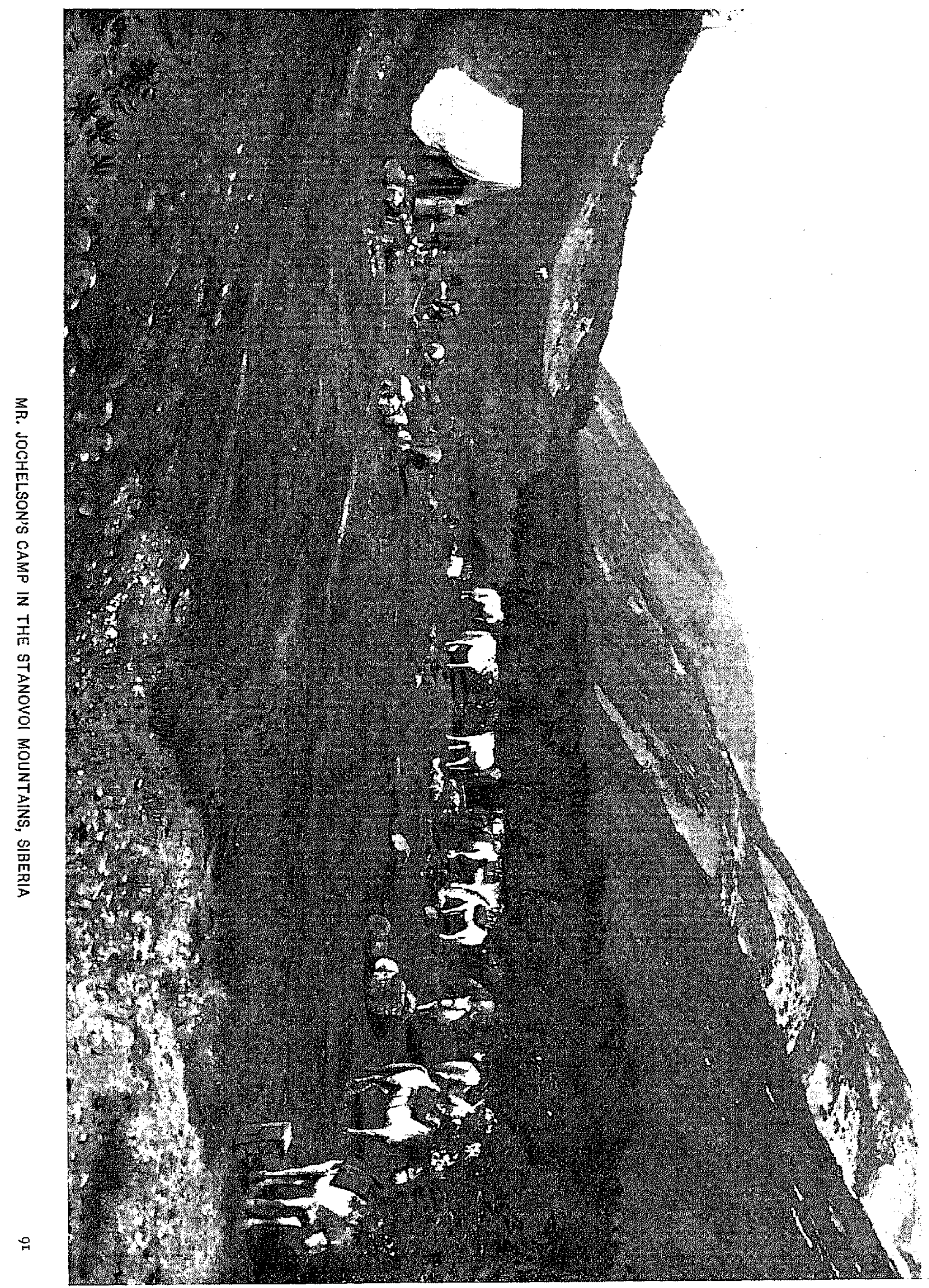




\section{THE AMERICAN MUSEUM JOURNAL}

Then he proceeded to the coast, and by appointment met Mr. Hunt at the northern end of Vancouver Island. There he spent the whole summer, visiting the fishing villages of the Indians and carrying on studies on their languages and customs. He also made a collection of plaster casts of Indian types.

On his return journey $\mathrm{Mr}$. Teit met $\mathrm{Dr}$. John $\mathrm{R}$. Swanton, who was about to visit Queen Charlotte Islands in order to study the Haida Indians. In September, r900, Dr. Swanton was conveyed by steamer to Skidegate, where he located for the winter. The Haida, who in former times lived in numerous villages all along the coasts of the islands, are so much reduced in numbers that they are now confined to two villages, while a portion of the tribe has located in southern Alaska. After several months spent at Skidegate, Dr. Swanton went to Masset, the northern village of the Haida, by canoe, and later visited Alaska. Finally he returned to Skidegate to take up some loose ends of his work, and returned east after a stay among the Haida which extended over more than a year. His work was supplemented by that of Dr. Charles F. Newcombe, who visited all the deserted villages of the Haida in a small boat, getting information on their exact location and on the geography of the country. At the same time he made a collection of plants.

In the years 1901 and r 902 Messrs. Hunt and Teit continued their studies for the expedition.

The isolated tribes along the east coast of Asia embrace the Ainu of Yezo and Saghalin, the Gilyak of the Amur River, the Kamchadal of the Peninsula of Kamchatka, the Koryak of the north coast of the Sea of Okhotsk, the Chukchee of the extreme northeastern part of Siberia, the Chuvantzy of the region west of the Chukchee and the Yukaghir of the Kolyma. In comparatively recent times Tungus tribes have settled in the territory which was probably originally inhabited by the other tribes alone.

The investigations on the Amur River were intrusted to Dr. Berthold Laufer and Mr. Gerard Fowke. Dr. Laufer had devoted himself to the study of the Tibetan language and of the history of Asiatic cultures, and was well prepared to take up the 


\section{THE AMERICAN MUSEUM JOURNAL}

problems offered by the Amur tribes. Mr. Fowke had done much archeological work in America, and he was to carry on archeological researches in the Amur province. Unfortunately the departure of the expedition was delayed by the difficulty of obtaining the necessary permissions and passports from the Russian Government. These obstacles were eventually overcome through the assistance of the United States Embassy in St. Petersburg, and through the active interest taken in the investigations by the Imperial Academy of Sciences of St. Petersburg. Dr. Laufer and Mr. Fowke arrived at Vladivostok on June I9, I898, and proceeded thence to Khabarovsk, on the Amur. Here they separated. Mr. Fowke descended the Amur in a boat, investigating the remains along both banks of the river.

Dr. Laufer went down the river by steamer, and crossed to the Island of Saghalin, which he reached on July ro, I898. He staid on the island until March $2 x$, I 899 , investigating the Gilyak, Tungus and Ainu tribes. The fall of 1898 he spent among the Gilyak tribes of the northeastern part of Saghalin; later he travelled southward along the east coast of the island. Unfortunately in October, when visiting a Gilyak village about twelve miles inland, Dr. Laufer was taken ill with the grippe, which was followed by pneumonia, so that his investigations suffered a long interruption. When hardly well enough to resume his work, he journeyed southward, at first on horseback and then on reindeer-sledges, visiting the Tungus and Ainu of the central and southern parts of the island. When about to continue his journey farther southward, he received a telegram from the Russian Governor, informing him of the presence of a band of desperadoes, who had built a fort in that region and had terrorized the whole country. Nevertheless he spent enough time among the Ainu to collect a considerable amount of valuable information.

On March 4, r899, he reported on the progress of his work as follows :

Among the collections which I made on the Island of Saghalin there are several very interesting specimens. I obtained from the Olcha Tungus a collection of wooden idols and amulets made of fish- 


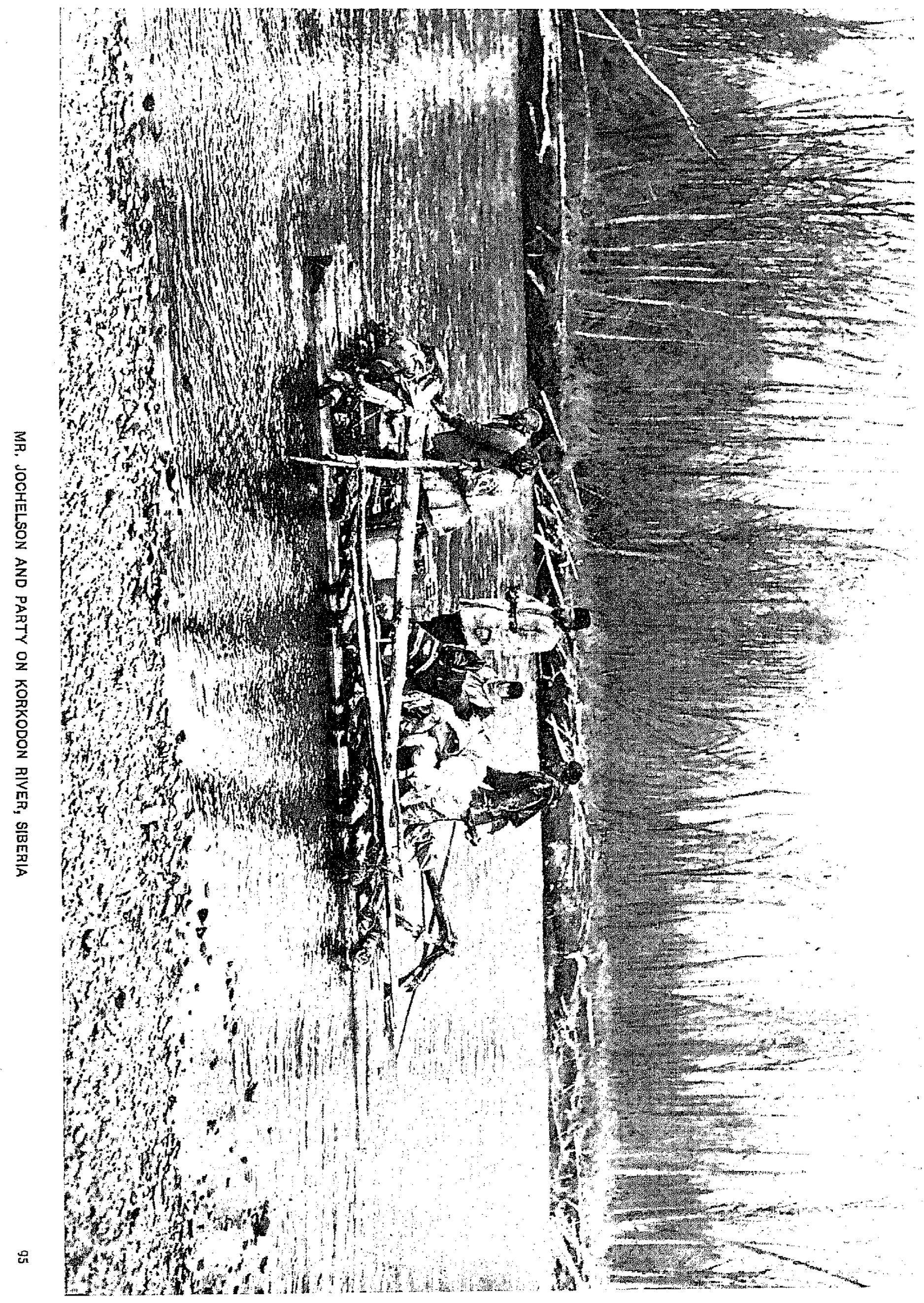




\section{THE AMERICAN MUSEUM JOURNAL}

skin which are quite new to science. I have had very good success in using the phonograph, and have obtained songs of the Gilyak and Tungus. Linguistic work on Saghalin was very difficult, because there are no interpreters capable of translating texts. There is no one who knows more than the most common phrases of Russian. Among the Ainu, Russian is entirely unknown; and for the purpose of interpreting I had to use Japanese, with which, however, they are not very familiar either. Nevertheless, my knowledge of the Japanese language facilitated my work among them since they like the Japanese people. I collected most of my material among the Ainu during the night-time, because it is only at this time that everything is active. There is a great difference between the Ainu dialects of Yezo and Saghalin, the latter being much more archaic. I did not succeed in obtaining any anthropometric measurements. The people were afraid that they would die at once after submitting to this process. Although I had their confidence, I failed in my efforts in this direction, even after offering them presents which they considered of great value. I succeeded in measuring a single individual, a man of imposing stature, who, after the measurements had been taken, fell prostrate on the floor, the picture of despair, groaning, "Now I am going to die to-morrow!"

I started comparatively late on my journey along the east coast of Saghalin, because I was detained for two months and a half by a severe attack of influenza. As soon as I had sufficiently recovered, I visited one of the Gilyak villages where the people were celebrating one of their bear festivals. I was welcomed with much delight, since I met several of my acquaintances of last summer. For five days I assisted in the ceremonial, and was even permitted to witness the sacrifice of the dog, which is kept secret from the Russians. . . . On New Year's eve I reached my southernmost point on the island. On the following day I took phonographic records of songs, which created the greatest sensation among the Russians as well as among the natives. A young Gilyak woman who sang into the instrument said, "It took me so long to learn this song, and this thing has learned it at once, without making any mistakes. There is surely a man or a spirit in this box which imitates me!" and at the same time she was crying and laughing with excitement.

On the $2 \mathrm{~d}$ of January I started by dog-sledge northward. This journey was exceedingly difficult, and sometimes even dangerous. At one time I narrowly escaped drowning when crossing the ice at the foot of a steep promontory. I broke through the ice, which was 


\section{THE AMERICAN MUSEUM JOURNAL}

much weakened by the action of the waves. Fortunately my guide happened to upset his sledge at the same moment when I broke through. Thus it was that he saw my situation, and extricated me with his staff.

Toward the end of the month I arrived at Korsakovsk, making the last hundred versts (sixty-seven miles) on horseback. Originally $I$ intended to return from this point along the west coast of the island; but this proved to be impossible, since there is no means of communication in winter. For this reason I had to return northward the same way that I came, and had to travel as rapidly as possible in order to reach Nikolayevsk in time, for by the end of March it becomes impossible to cross the ice between the island and the mainland. Therefore I returned with all possible speed; working and collecting, however, whenever opportunity offered.

On March 2 I Dr. Laufer crossed to the mainland in order to take up his studies of the Gold, a Tungus tribe. He reached Khabarovsk on March 25. Since a considerable number of Gold are located at that point he settled there and carried on his investigations among the natives. By the end of May, navigation on the Amur being reopened, he started on a boat journey down the river, visiting villages of the Gold, and farther down those of the Gilyak. After reaching Nikolayevsk, he paid a visit to the Gold tribes on the Amgun River, and finally returned to Vladivostok. On October I9, I899, Dr. Laufer started home, and after spending some time in Japan, reached New York early in r900. Mr. Fowke had left Vladivostok a little earlier, and reached New York in the fall of 1899.

The plans for the work in the arctic part of Siberia were elaborated with the assistance of the Imperial Academy of Sciences of St. Petersburg. Professor W. Radloff, director of the Ethnographical Museum and a member of the Academy, suggested that the work be intrusted to Messrs. Waldemar Jochelson and Waldemar Bogoras, who had for several years carried on important studies in Siberia under the auspices of the Imperial Geographical Society. In the summer of 1898 Professor Boas visited Europe, and, after consultation with Professor Radloff, had a number of conferences with Mr. Jochelson, in which the 


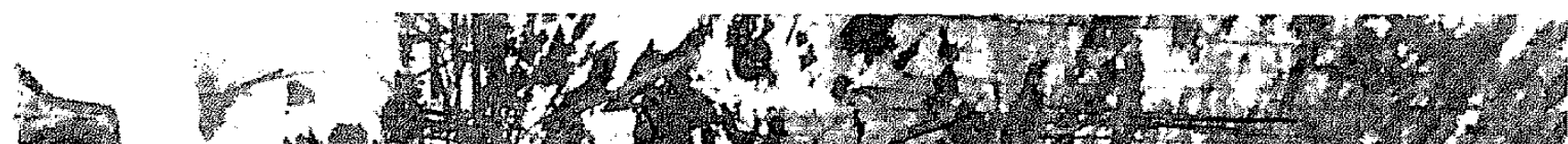

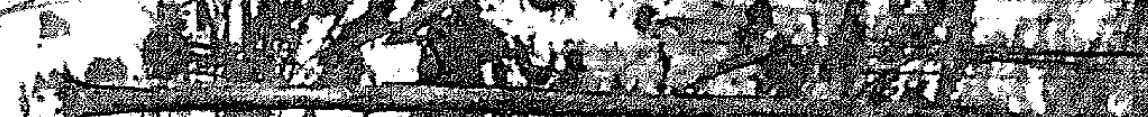
(1)

(t)

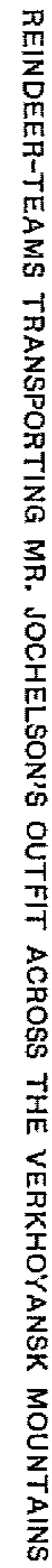

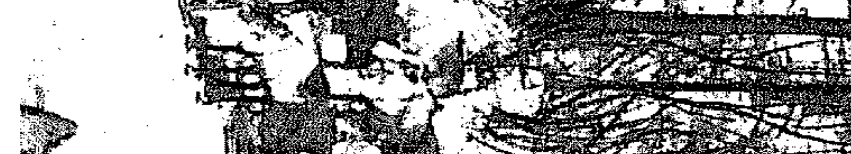

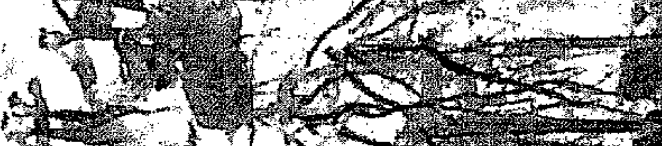

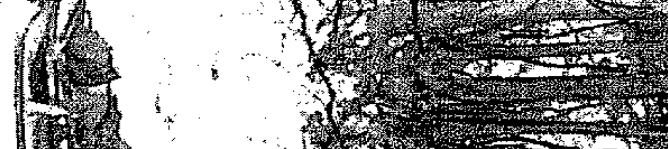

Wrow

1.

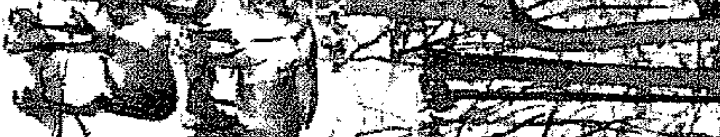

1) 1 (1)

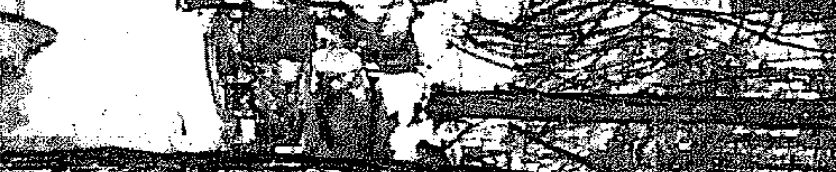

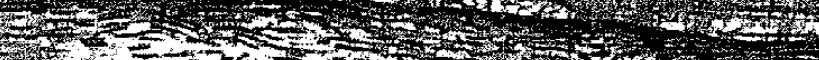

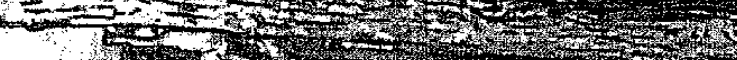

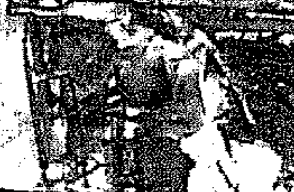

(1)

列

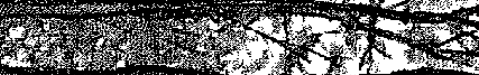

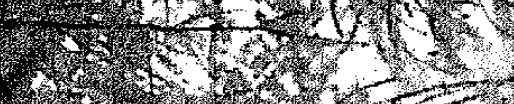

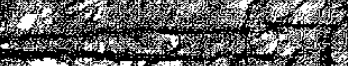

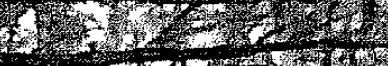

3.

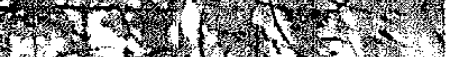

. 34.5 . 5 ?

$3 \times 12$

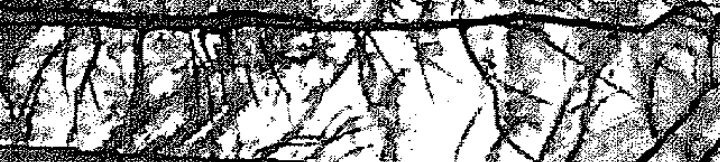

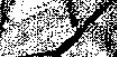

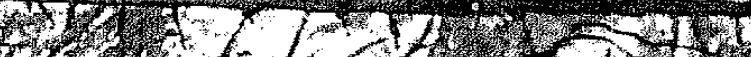

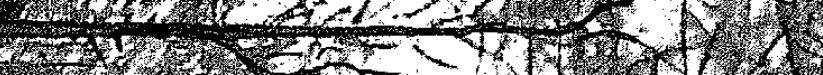

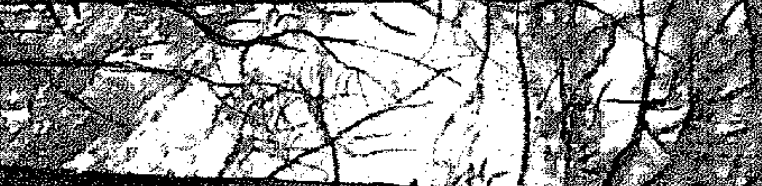

7.

5,2474

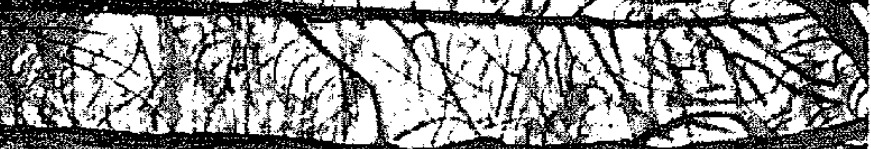

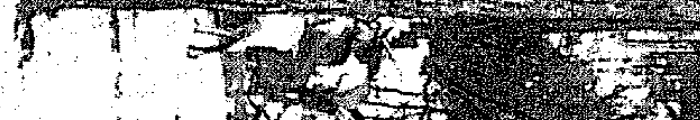

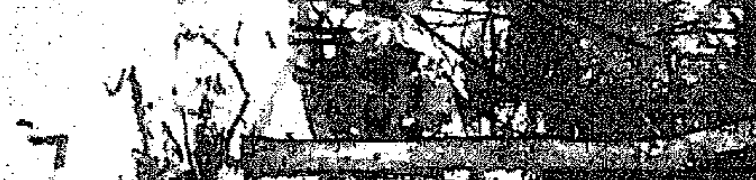

1.

(4)

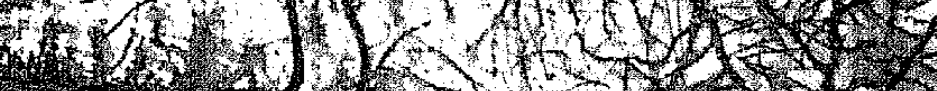

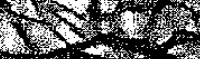

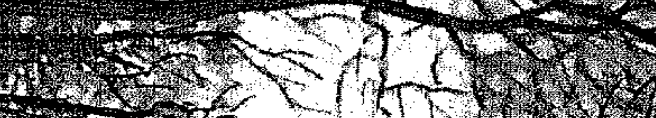

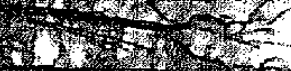

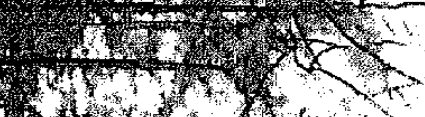

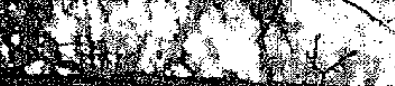

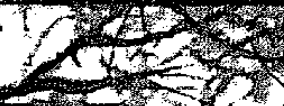




\section{THE AMERICAN MUSEUM JOURNAL}

general plan of the expedition was decided upon. According to this plan, Mr. Jochelson was to undertake the study of the Koryak and Yukaghir; Mr. Bogoras, that of the Chukchee and Eskimo. Through their former expeditions $\mathrm{Mr}$. Jochelson was already familiar with the Yakut and part of the Yukaghir, while Mr. Bogoras knew the western Chukchee intimately. The expedition was to begin in the year I900. Mr. Bogoras was to stay among the Chukchee and Eskimo until the summer of Igor, while Mr. Jochelson proposed to begin his studies on the Sea of Okhotsk, and then to travel westward over the Stanovoi Mountains to the Yukaghir, whence he intended to return by way of Yakutsk and Irkutsk in r9o2. Later this plan was slightly modified, in that Mr. Bogoras undertook the linguistic study of the Koryak, whose speech is closely related to that of the Chukchee.

Messrs. Jochelson and Bogoras reached New York in March, I900. A considerable part of the outfit of the expedition had been purchased in Europe and shipped to Vladivostok direct. The rest of the purchases were made in America, and in April the party left San Francisco bound for Vladivostok, which was reached May I6. In New York Mr. Norman G. Buxton was added to the party. He was charged with the making of collections of zoölogical material. Mrs. Jochelson and Mrs. Bogoras, who were to share the hardships of the journey with their husbands, and to undertake part of the work of the expedition, had gone to Vladivostok by way of the Trans-Siberian Railway. Besides, Mr. Jochelson had engaged Mr. Alexander Axelrod of Zürich as a general assistant, particularly for carrying on the geographical work incidental to the expedition. Mr. Jochelson undertook the general leadership.

At Vladivostok the expedition separated into two parties. Mr. and Mrs. Jochelson and Messrs. Axelrod and Buxton were to make their headquarters at Gishiga; Mr. and Mrs. Bogoras, at Mariinsky Post, at the mouth of the Anadyr River. The Bogoras party left Vladivostok on June I4, on board the steamer "Baikal." The departure of the Jochelson party was delayed until July 24, because, owing to the political complications in China, the gov- 


\section{THE AMERICAN MUSEUM JOURNAL}

ernment transport "Khabarovsk," which visits Gishiga once every year, was employed for military purposes.

Mr. Jochelson reports on the progress of the expedition in his immediate charge as follows:

On August 16, I900, we landed in Kushka, a small village at the mouth of the Gishiga River. The condition of affairs in the district of Gishiga was very sad. In the winter of $1899-1900$ this region had been visited by an epidemic of measles. According to the church registers, 179 persons out of a total of 500 had died at Gishiga between December 25, I899, and March I, I900. When we reached Gishiga, the grippe prevailed and everybody was sick abed. Contrary to my expectations, there were no Koryak near Gishiga. The Reindeer Koryak, who are in the habit of wintering near this place, had moved far into the mountains with their herds, in order to escape the ravages of the prevailing epidemic. Neither was it easy to reach the villages of the Maritime Koryak, which are located on Penshina Bay, east of Gishiga. There is no regular means of communication in summer, because at that season travel across the tundra by dog-or reindeer-team is impossible. Sea-going boats which could withstand the heavy seas at Cape Taigonos, between the bays of Gishiga and Penshina, were not available, so that, in order not to lose the remaining summer months, I made up my mind to attempt the tundra with pack-horses. These, however, were hard to get. There were sixtyfive horses in all, in the region, the property of the Russian inhabitants of Gishiga. Most of these had been hired by a Russo-American gold-mining company, which was represented by an American engineer, Mr. Shockley. After a great deal of trouble I succeeded in hiring twenty horses, some of which were almost too young for use. Mr. Buxton staid in Kushka in order to make zoölogical collections, while the rest of our party started on September ro.

We were accompanied by a Cossack, an interpreter and two packers, who also served as guides. The trail across the boggy tundra and over the hills was very difficult. Pack-horses as well as saddlehorses became mired and had to be extricated, so that we did not average more than ten miles a day. One day, while our Cossack and interpreter were hunting two pack-horses that were carrying provisions and had run away up a side valley, I tried to proceed on my journey, accompanied by Mrs. Jochelson and Mr. Axelrod. We ex- 


\section{THE AMERICAN MUSEUM JOURNAL}

pected soon to overtake our guides, who had gone ahead with the rest of the pack-horses; but when ascending a hill we lost the trail, and for two days we wandered about in the high, treeless tundra without food, fire or protection against wind and frost. At length we gathered a large pile of wood and started a fire, the smoke of which was discovered by our men, who had been searching for us all the time. At the foot of the last pass we had to cross we were overtaken by a snowstorm, which detained us for three days. At length on October 5, we reached Paren, a winter village of the Koryak. The village, however, was deserted, since the people were still living in their summer village, about fifteen miles distant. I sent my men to notify them of our arrival, and on the following day two skin boats arrived at the mouth of the river to convey us to the village Kuel, on the river of the same name. Before our departure from Paren, I sent back my two guides with the horses, which were exhausted by the long journey. The return journey of these men lasted eighteen days, and was full of accidents. In a snowstorm they lost six horses, the men themselves almost perished of cold and hunger, and after their arrival in Gishiga six more horses died of exhaustion.

After our arrival at Kuel, our investigations began. During the first half of the winter I900-or we carried on our work in the villages of the Maritime Koryak of the bays of Gishiga and Penshina. The second half of the winter was spent in the camps of the Reindeer Koryak in the interior of the country. When the winter trails were in good condition, I went to Gishiga to replenish my provisions and barter, and then we started with twenty dog-sledges for Kamenskoye, where I staid for some time.

While we were located at this place, Mr. Bogoras came overland on a visit from Anadyr, and spent the month of December with us. During this time he was engaged in studies of the Koryak language. After his arrival, I sent Mr. Axelrod to Anadyr to take charge of Mr. Bogoras's station until his return. Mr. Bogoras completed his linguistic studies, and then proceeded to visit the villages of northern Kamchatka. After his return, Mr. Axelrod staid with him at Anadyr.

In all my journeys I was accompanied by Mrs. Jochelson, who, being a candidate for the degree of medicine at the University of Zürich, took charge of the anthropometrical and medical work of the expedition and of most of the photographic work.

While among the Maritime Koryak, we lived most of the time in 


\section{THE AMERICAN MUSEUM JOURNAL}

their underground dwellings, which are reached by a ladder leading down through the smoke-hole. It is almost impossible to describe the squalor of these dwellings. The smoke, which fills the hut, makes the eyes smart. It is particularly dense in the upper part of the hut, so that work that has to be done in an upright position becomes almost impossible. Walls, ladder and household utensils are covered with a greasy soot, so that contact with them leaves shining black spots on hands and clothing. The dim light which falls through the smoke-hole is hardly sufficient for writing and reading. The odor of blubber and of refuse is almost intolerable; and the inmates, intoxicated with fly agaric, add to the discomfort of the situation. The natives are infested with lice. As long as we remained in these dwellings we could not escape these insects, which we dreaded more than any of the privations of our journey.

The winter tents of the Reindeer Koryak are so cold that we could not work in them; therefore we had to put up a tent of our own. It was furnished with a small iron stove, and there we carried on our ethnological and anthropometrical work. At night, however, the tent was very cold, and we slept in bags made of wolf-skins. While on the way, we spent the nights on the snow, covered with fur blankets. Several times we were exposed to snowstorms, and had to wait under our blankets, covered with snow, until the gale was over.

In May we returned to Kushka, and I was engaged until June in packing up and cataloguing the collections which we had made in the winter. In June we started in two boats on the dangerous journey to the mouth of the Nayakhan River. At that time there were assembled at this place more than sixty tents of nomadic Tungus whom I proposed to visit. On our return journey the tempestuous sea drove us into the Bay of Atykyna, where we had to stay for five days, almost without any provisions. Fortunately on the fourth day of our stay my men killed two seals. In July I made a trip by boat from Gishiga to the mouth of the river Ovekova, where I visited a camp of Maritime Koryak. This was my last stay with the Koryalk, and on July $28 \mathrm{I}$ returned to Kushka.

While Mr. Bogoras's party was returning to Vladivostok from Mariinsky Post, and while Mr. Buxton was waiting for the steanner that was to take him back, I had to stay another year in northeastern Siberia, the object of my further investigations being the study of the Yukaghir of the Kolyma. 


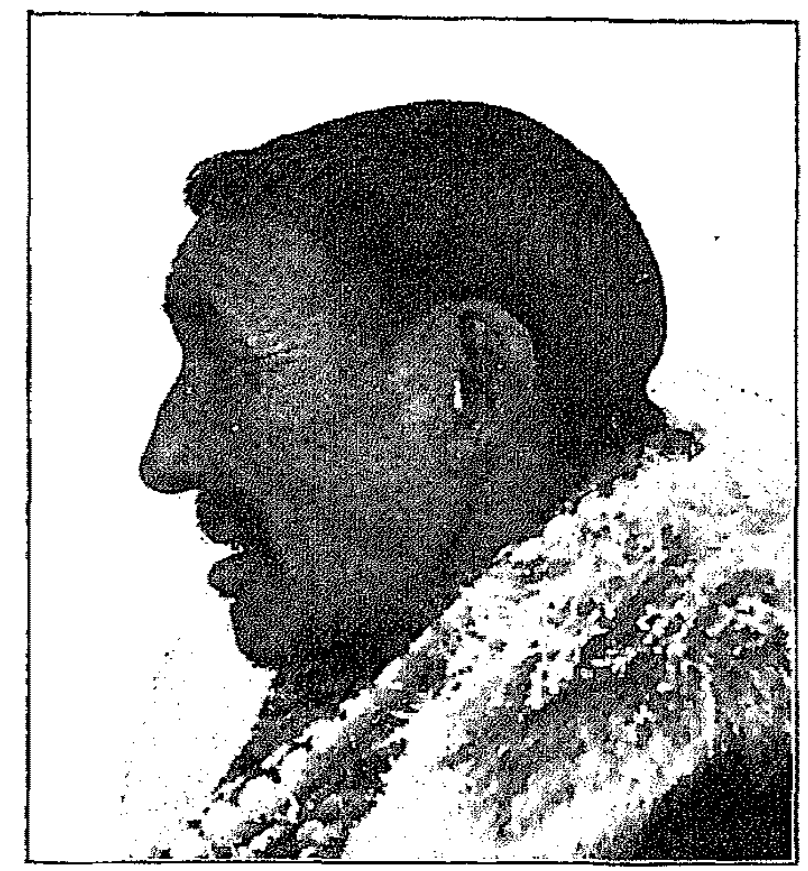

CHUKCHEE

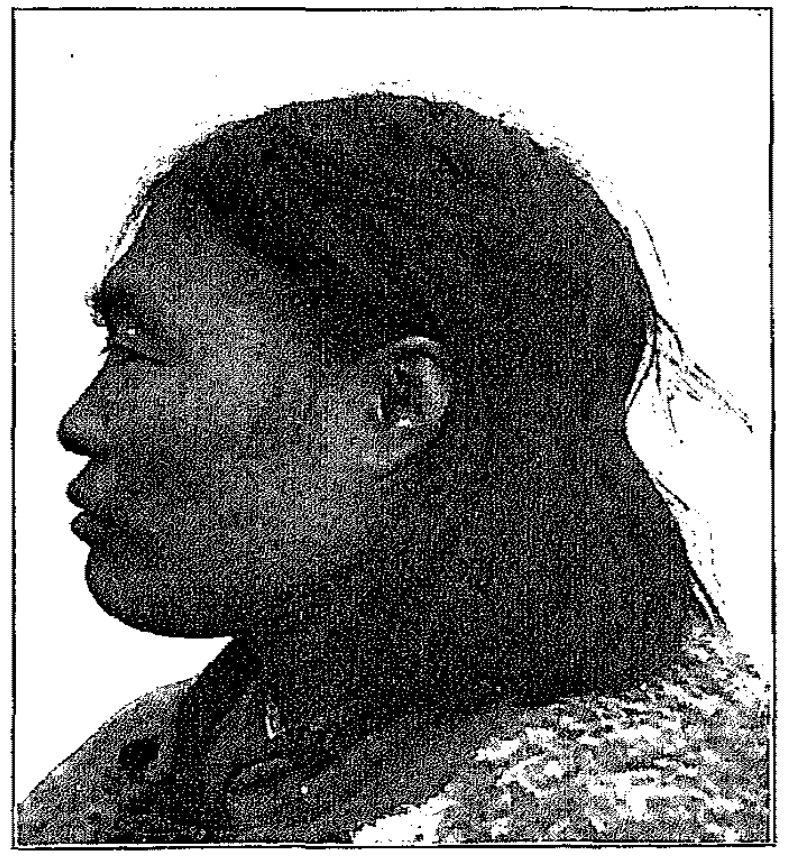

YUKAGHIR

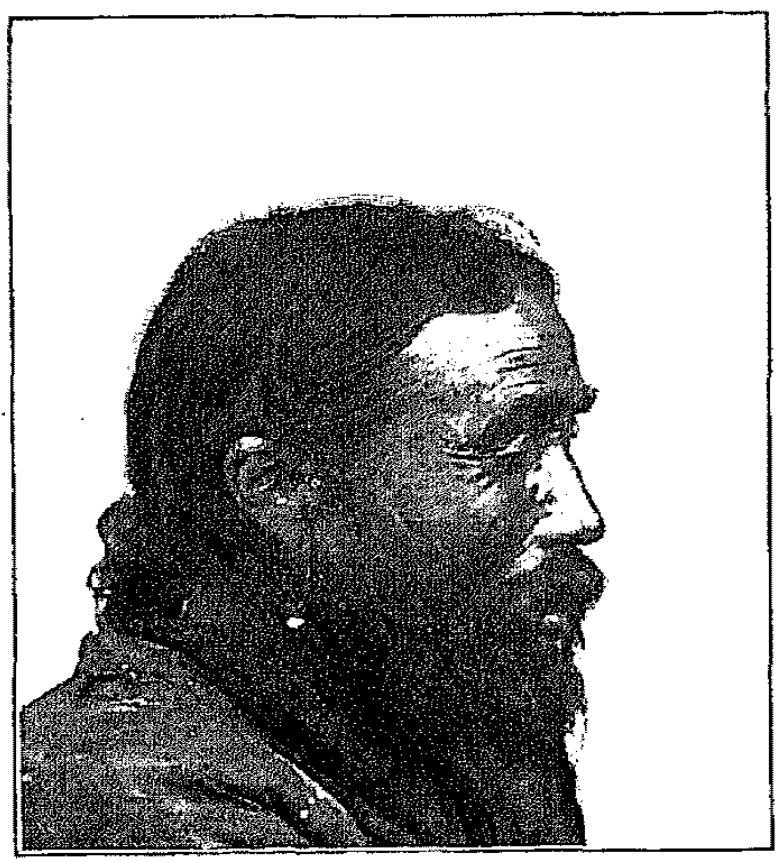

I05

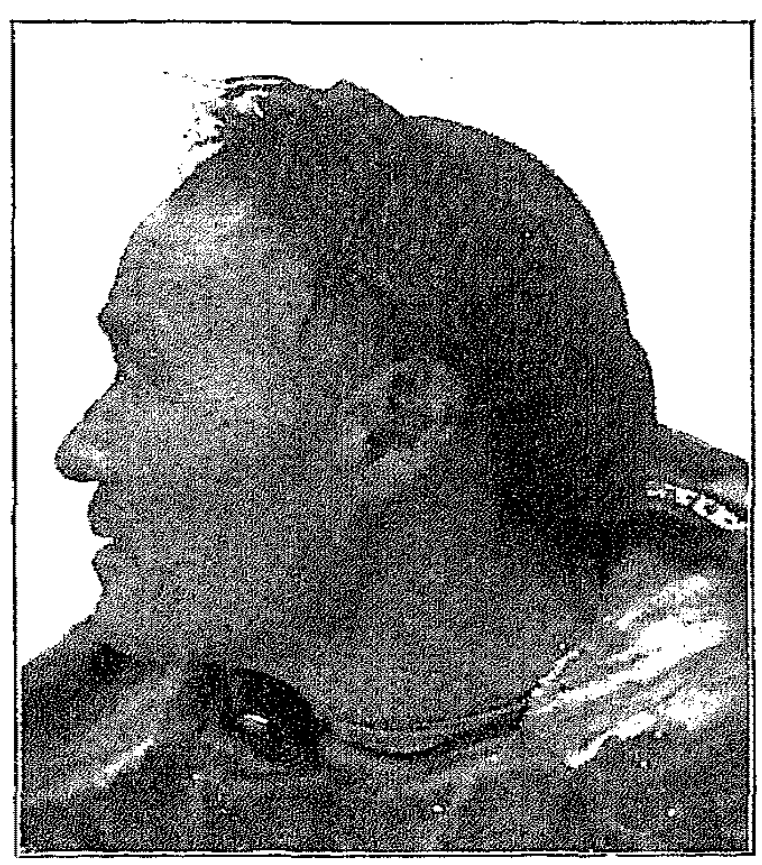

KORYAK

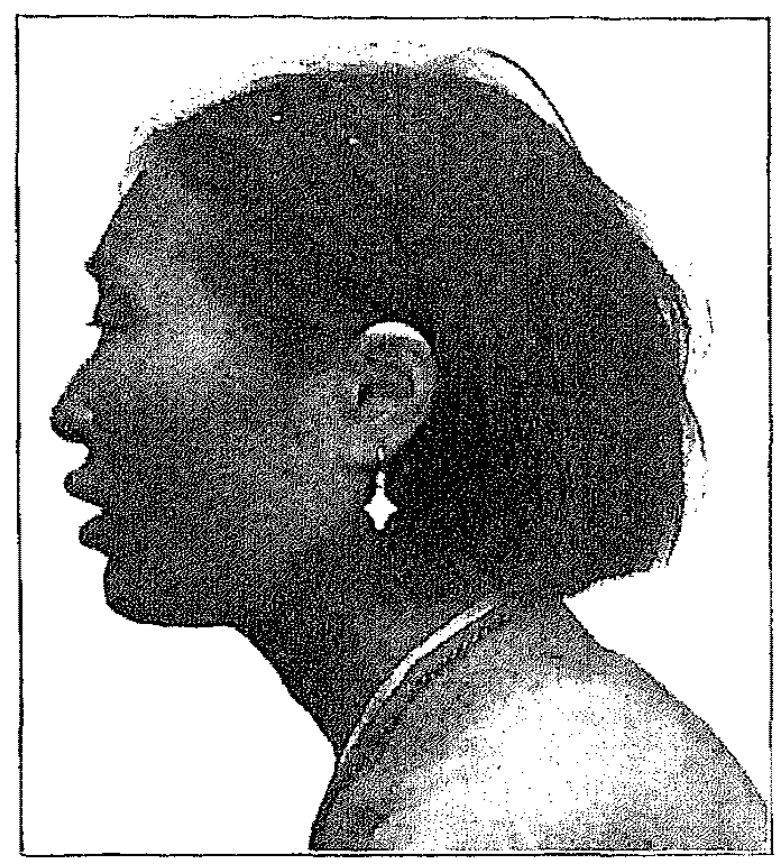

TUNGUS

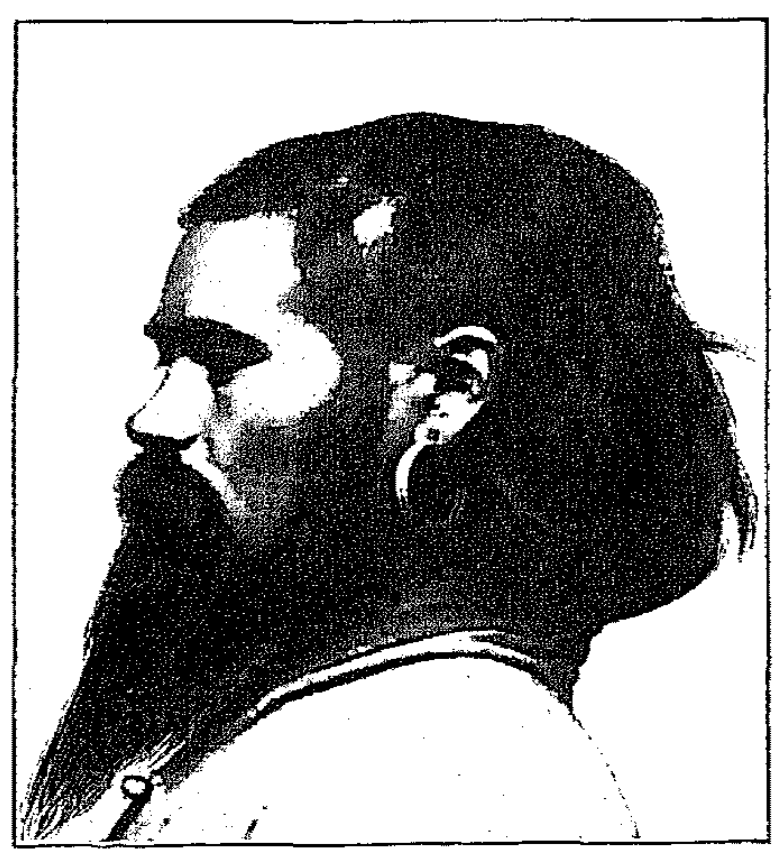

Alno 


\section{THE AMERICAN MUSEUM JOURNAL}

After the necessary preparations had been completed, I started with Mrs. Jochelson on August I 5 from Kuslika, on our journey across the Stanovoi Mountains to the Kolyma. I had hired twenty saddle- and pack-horses from the Yakut, and was accompanied by four Yakut packers, one Tungus guide, one Tungus interpreter and one Yukaghir chief.

Our journey from Kushka, at the mouth of the Gishiga River, to Verkhne-Kolymsk, on the Yassachna River, a tributary of the Kolyma, took fifty-six days-from August I 5 until October 9, Igor. We were the first whites to cross the Stanovoi Mountains at this point. In winter, nomadic Tungus visit this country, but in summer it is deserted by all human beings. This journey was the most difficult one that it was ever my fate to undertake. Bogs, mountain torrents, rocky passes and thick forests combined to hinder our progress. Part of our provisions consisted of bread and dried fish. A heavy rain which fell during the first few days of our journey soaked the loads of the pack-horses and caused the provisions to rot. Therefore we had to cut down our rations from the very beginning. After crossing the passes of the Stanovoi Mountains, we reached the upper course of the Korkodon River. By this time our horses were exhausted, and it was necessary to take a long rest. Meanwhile the cold was increasing day by day, and haste was necessary if we were to reach Verkhne-Kolymsk before the closing of the river. Therefore I left three Yakut with the horses and the goods, and prepared to descend the river on a raft with the rest of my party, hoping thus to reach a camp of the Yukaghir which is located on the course of the Korkodon.

It took us one day to build a strong raft, and then we began the descent of the river, made dangerous by numerous rapids and short bends, by the rocky banks and by jams of driftwood. Our guides had intimated that we could make the descent in two days, but instead we spent nine days on the raft. It was my desire to leave ample provisions with the three Yakut who staid with the horses, and for this reason I had reduced our own allowance to the very lowest limit. Thus it happened that three days' rations had to last us through the nine days which we spent on the raft. For the last six days we had to be satisfied with forty-five pounds of flour, or an allowance of two cups a day for every person and a little tea without sugar.

We spent four days among the Yukaghir of the Korkodon, and after finishing our work and purchasing a supply of fish, we continued our journey to Verkhne-Kolymsk in a boat down the Korkodon and 


\section{THE AMERICAN MUSEUM JOURNAL}

the Kolyma. The journey took seven days. In the night following the seventh day the river froze up while we were still forty miles from our goal. We left the boat, and after a tramp of two days reached Verkhne-Kolymsk on October 9, I90 x. There I found the goods which I had sent ahead in 1900 from the Bay of Ola. From Verkhne-Kolymsk, a village of eight houses and one church, I visited the Yukaghir of the River Yassachna. It was December 8 when the Yakut whom I had left on the Korkodon reached Verkhne-Kolymsk. Then we proceeded to Sredne-Kolymsk, the capital of the district and a town of five hundred inhabitants, arriving there December 24 . On January 6, I902, we continued our journey to Nishne-Kolymsk, and then to the Yukaghir of the tundra west of the Kolyma. February I 5 we returned to Sredne-Kolymsk, and March 6 started on our return journey. Passing Verkhoyansk we reached Yakutsk April 25, I902.

The condition of affairs in northeastern Siberia happened to be very unfavorable during the time of my visit. A famine prevailed among the Yukaghir of the Yassachna. I assisted them as far as I could, and sent a messenger to Sredne-Kolymsk to request the assistance of the government. In the spring of 1902 the inhabitants of three Yukaghir tents on the Omolon were found starved to death. Even in Sredne-Kolymsk the fishing had been a complete failure, and the people were compelled to kill their dog teams because they could. not feed them. Hunting on the tundra had also been a failure. Besides this, there were unusual demands made upon the horses and reindeer that are used as means of conveyance on the post-road from Yakutsk to Kolymsk, so that the animals were quite exhausted. On this road we met officers from Yakutsk, government messengers, and members of several expeditions:- the Mammoth expedition of the Imperial Russian Academy of Sciences, part of the polar expedition of Baron von Toll, and the English newspaper expedition of Harry de Windt. For these reasons the conveyance of the Yukaghir collections to Yakutsk was very difficult. We spent some time in the district of Yalkutsk, where I made a Yakut collection. We started homeward July 16, I902; reached Irkutsk August 8, where we took the railroad for St. Petersburg, and finally arrived at New York November I8, I902.

The distance covered by myself and Mrs. Jochelson from Gishiga to Irkutsk amounted to nearly eight thousand miles. The results of our work are complete studies of the ethnography and anthropology of the Koryak and Yukaghir, illustrated by extensive collections. 


\section{THE AMERICAN MUSEUM JOURNAL}

These collections embrace three thousand ethnographical objects, forty-one plaster casts of faces, measurements of about nine hundred individuals, twelve hundred photographs, one hundred fifty tales and traditions, phonographic cylinders, and skulls and archæological specimens from abandoned village sites and from graves. I also made a small zoölogical collection, and obtained a large mammoth tusk weighing two hundred twenty pounds. During the whole period of my absence I kept a meteorological journal.

Mr. Jochelson does not state in this report that on his whole journey overland to the Kolyma, and from there through the clistrict of Yakutsk, certain Russian officials, following a secret order issued by the Minister of the Interior, did all they could to hinder the progress of the expedition and to thwart its success. This action seems difficult to understand, in view of the hearty support and assistance rendered by the Imperial Academy of Sciences and the open letters issued by the Russian Government, requesting the officials of Siberia to render assistance whenever possible.

Mr. Bogoras gives the following description of his expedition:

We left Vladivostok June I4, I900, for Mariinsky Post at the mouth of the Anadyr River, taking the only regular means of conveyance, the Russian mail steamer, which visits the place but once a year. Contrary to my expectations, I had not been able to charter a special steamer to carry the Anadyr branch of the Jesup North Pacific Expedition to the Chukchee Peninsula.

Mariinsky Post is the most remote settlement of the Russians in northeastern Asia. We arrived there after a five weeks' journey. A detachment of Cossacks is stationed there, by the side of a small native village. The Cossacks live in barracks built of timber and covered all over with earth. The native village is the southernmost settlement of the Maritime Chukchee, and is distant several days' journey from the nearest village of the same tribe. On account of an epidemic of measles which was ravaging the Chukchee villages, I could not hire a boat's crew for a journey to the north. Therefore I had to delay my visit to the northern villages until the next spring, when I crossed Holy Cross Bay on the ice. Before starting I had arranged to meet Mr. Jochelson at Kamenskoye, on the Sea of Okhotsk, where I was to spend some time studying the Koryak language. I also 


\section{THE AMERICAN MUSEUM JOURNAL}

thought that it would be possible to proceed from. Kamenskoye to northern Kamchatka, in order to study such remnants of the Kamchadal language and folk-lore as might still exist in some remote villages, and then to return to Anadyr in time for a journey northward.

I spent the first four months of my field-work at the mouth of the Anadyr, visiting the camps of the Reindeer Chukchee, which during the summer are scattered on the seashore. I made collections and took photographs and anthropometrical measurements. During this time I also made a study of the language of the $\mathrm{Ai}^{\prime}$ wan tribe, which forms the main branch of the Asiatic Eskimo. In this I had the aid of two $\mathrm{Ai}^{\prime}$ wan families who live with the Chukchee at Mariinsky Post. The conditions of the summer were rather unfavorable. An epidemic of measles brought by a Russian trader from Vladivostok to Kamchatka the previous year swept along the shores of the Sea of Okhotsk and of Bering Sea, carrying away hundreds of victims. In some places the fatality amounted to about thirty per cent. of the whole population. In the summer of $x 900$ it reached the Pacific shore of the Chukchee Peninsula, where the loss of life was just as considerable. Therefore the summer fair which is held at Mariinsky Post early in August every year was not visited in $\mathrm{r} 900$ by any of the native traders from the northern Chukchee and the Eskimo villages.

About the end of October, a considerable time after the freezing of the Anadyr River, I left Mariinsky Post, together with one of my Cossacks, bound for the village of Markova on the middle Anadyr, from there to Kamenskoye on the Okhotsk Sea. From that period till the end of my field-work I spent my time in continuous travel, and did not remain at any one place more than three or four weeks. Mrs. Bogoras staid on the Anadyr till the next summer, traveling between Mariinslky Post and Markova, and making the greater part of the collections for the Museum, while I spent my time chiefly in collecting scientific information. She was assisted by $\mathrm{Mr}$. Axelrod, whom Mr. Jochelson sent to Mariinsky Post from Kamenskoye.

We traveled almost exclusively with dogs, several of which I bought from the natives, picking out the best, and from time to time exchanging for fresh ones those that became unfit for further travel. Of these dogs I formed three teams, which allowed us to travel fast enough, when the weather and the conditions of the snow were favorable. We could carry no heavy loads, however, and had to leave everything behind except our scientific instruments and a few objects for barter. This obliged us to rely almost wholly on the food-supply 


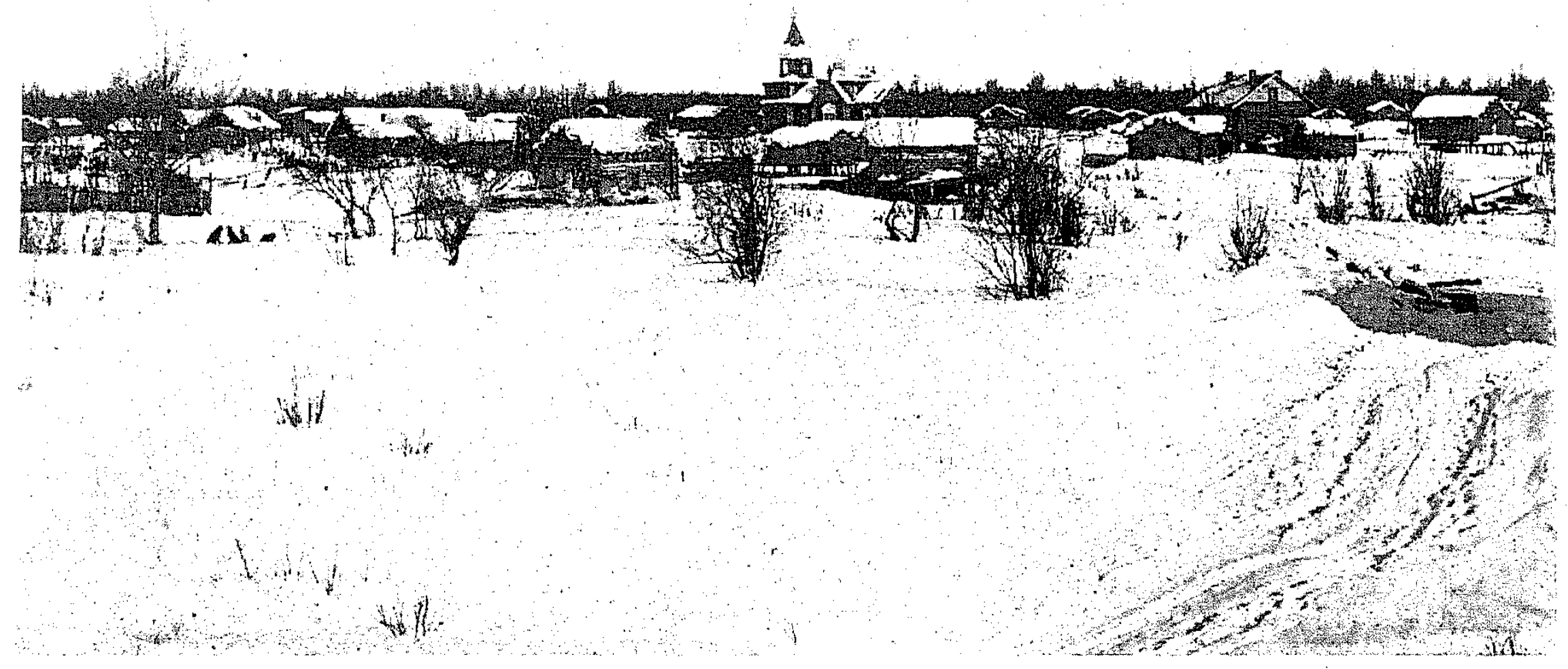




\section{THE AMERICAN MUSEUM JOURNAL}

of the country, and during the whole time we lived on dried fish, reindeer-meat, seal and walrus blubber etc. I found it more difficult to get food for my dogs than for ourselves especially in the spring, when food is scarce in the maritime villages. Thus we were obliged to carry some dog-food all the time, which lessened still more our carrying-capacity for other purposes. In traveling I was usually accompanied by one Cossack and a native guide. Each of us drove his own team of twelve animals.

The winter of r9oo-or was very severe in the Anadyr country. It began with heavy snowfalls, which were followed by a general thaw. The moss pastures were covered with a crust of ice, and thus the reindeer herds were half starved because they could not break the ice with their hoofs. Therefore the winter fairs were sparsely attended, the people remaining scattered all around the country, unable to undertake any extensive journeys. Blizzards were frequent, and directly after leaving Mariinsky Post we were overtaken by one which lasted several days and spoiled the track to such a degree that our dogs were hardly able to drag themselves through the deep snow. We had to make the greater part of the journey to Markova on snowshoes and assist our teams in dragging the sledges.

I reached Kamenskoye after a month's journey, and found Mr. and Mrs. Jochelson there. Near the end of December, after four weeks' stay, I left Kamenskoye, and went across the plateau of Parapolsky Dol to the first villages of the Kamchatka Koryak, and thence to the villages of the western Kamchadal, on the west coast of the Kamchatka Peninsula. There, in eight villages, I found that the Kamchadal language was still spoken, though rapidly giving way to Russian. The language was found to belong to the same stock as the Chukchee and the Koryak. In several details the Kamchadal language appears to be more complicated and probably more ancient than the two northern dialects.

About the end of February I left Kamchatka and started on my return journey to the Anadyr, along the Pacific coast, through a part of the country hitherto wholly unknown and unexplored. The journey had to be made hurriedly, because I had to reach Mariinsky Post on March 25, since I had left directions with the Anadyr branch of the expedition to have everything ready by that time for a journey northwards. Unfortunately I was taken ill with influenza in one of the Kamchatka villages and lost my voice temporarily, so that I could communicate with the natives only by means of signs during 


\section{THE AMERICAN MUSEUM JOURNAL}

more than a fortnight. At one time, indeed, my illness became so alarming, that the Cossack, who also felt responsible for the success of the expedition, asked me for instructions as to which way to carry my body and my "official papers" in case I should die on the route. I ordered him to tie up everything in curried leather, and to take it with all possible despatch to the Anadyr.

My route lay across the border-line between the Koryak and the Chukchee reindeer-breeders, who in former times were involved in continuous warfare with each other, and then along the line of Kerek villages. The latter are a branch of the Maritime Koryak, who live in the most remote part of the country, which is very poor in natural resources. In former times they lived chiefly on walrus; but within the last few decades, $i . e$, since the arrival of American whalers has driven the walrus farther to the north, they have been rapidly dying out from continual starvation.

Between the Kerek villages and the first camps of the Anadyr Reindeer Chukchee lies an uninhabited, mountainous country. It is unknown to the Kerek, who therefore could not supply us with guides, and we had to pass through it, guided solely by the course of the frozen mountain rivers up to the watershed, and then down to the tributaries of the Anadyr. This journey lasted seventeen days, and nearly exhausted the strength of both dogs and drivers.

I reached Mariinsky Post on March 26, and after a stay of two weeks started northward with a party of native traders, who were returning from the annual traffic with the Anadyr Cossacks. I was accompanied by Mr. Axelrod and four Russianized natives with extra teams, carrying provision and wares for barter. During this journey Mr. Axelrod made a survey of the overland route. A journey of four weeks brought us to Indian Point, where we staid about a month, during which time I made a boat journey to St. Lawrence Island. My studies at that place were devoted to the Maritime Chukchee and Asiatic Eskimo.

At the end of June I started on my return journey towards the mouth of the Anadyr. For this purpose I bought the frame of a native boat and had it covered with walrus hicles. Our journey in this boat lasted thirty-two days, and we arrived at Mariinsky Post on July 28 , r $90 \mathrm{I}$, ten days before the arrival of the annual postal steamer which took us back to Vladivostok. From there I shipped our collections to New York by way of Suez, while we returned over the Trans-Siberian Railway to St. Petersburg. There I was unfor- 


\section{THE AMERICAN MUSEUM JOURNAL}

tunately taken ill, and was unable to return to New York until April I 7, I902.

The results of this work are studies of the ethnography and anthropology of the Chukchee and Asiatic Eskimo, and partly of the Kamchadal and of the Pacific Koryak. These studies are illustrated by extensive collections, embracing five thousand ethnographical objects, thirty-three plaster casts of faces, seventy-five skulls and archæological specimens from abandoned village sites and from graves. Other material obtained includes three hundred tales and traditions; one hundred fifty texts in the Chukchee, Koryak, Kamchadal and Eskimo languages; dictionaries and grammatical sketches of these languages; ninety-five phonographic records, and measurements of eight hundred sixty individuals. I also made a zoölogical collection and kept a meteorological journal during the whole time of my field-work.

The investigators who took part in the field-work of the expedition are all engaged in studies of the materials collected. Some of the results have been published, but much remains to be done. It is of course premature to draw any final conclusions from the materials collected, because the greater part is not yet available for purposes of comparison, and the investigation of the anthropometrical material has not even been taken up. It seems clear, however, even at this time, that the isolated tribes of eastern Siberia and those of the northwest coast of America form one race, similar in type, and with many elements. of culture in common. It would seem that the unity of race was much greater in former times than it is now; that the invasion of eastern tribes in America, such as the Eskimo, Athapascan and Salish, and of western and southern tribes in Asia, such as the Yakut and Tungus, have disturbed the former conditions. Nevertheless enough remains to lead us to think that the tribes of this whole area must be considered as a single race, or at least that their culture is a single culture, which at one time was found in both the northeastern part of the O1d World and the northwestern part of the New World. Thus the Jesup Expedition seems to have established the close relationship between the peoples of Asia and America. 


\section{THE AMERICAN MUSEUM JOURNAL}

The following Museum memoirs have been published, embodying results obtained by the Jesup North Pacific Expedition. The number of the volume is that which each bears in the series of Museum memoirs.

\section{Vol. II. Anthropology.}

PART I. - Facial Paintings of the Indians of Northern British Columbia. By Franz Boas. Pp. r-24, pll. i-vi. June x6, r898.

PART II. - The Mythology of the Bella Coola Indians. By Franz Boas. Pp. 25-I27, p11. vii-xii. November, I 898.

PART III. - The Archaology of Lytton, British Columbia. By Harlan I. Smith. Pp. I29-I6I, p1. xiii, and I I t text figtures. May, 1899.

PART IV. - The Thompson Indians of British Columbia. By James Teit. Edited by Franz Boas. Pp. I63-392, p11. xiv-xx, and I98 text figures. April, I900.

PART V. - Basketry Designs of the Salish Indians. By Livingston Farrand. Pp. 393-399, pll. xxi-xxiii, and I 5 text figures. April, I900.

PAR'T VI. - Archæology of the Thompson River Region. By Harlan I. Smith. Pp. 4OI-442, p11. xxiv-xxvi, and $5 \mathrm{I}$ text figures. (With title-page, contents, and index to Vol. II.) June, I900.

Vol. IV. Anthropology (not yet completed).

PART I. - Traditions of the Chilcotin Indians. By Livingston Farrand. Pp. I-54. June, I900.

PART II. - Cairns of British Columbia and Washington. By Harlan I. Stmith and Gerard Fowke. Pp. 55-76, pll. i-v, and 9 text figures. January, I9OI.

PART III. - Traditions of the Quinault Indians. By Livingston Farrand, assisted by W. S. Kahnweiler. Pp. 77-r 32. January, I902.

PART IV. - Shell-Heaps of the Lower Fraser River. By Harlan I. Smith. Pp. I33-I90, p11. vi, vii, and 59 text figures. December, I902. 


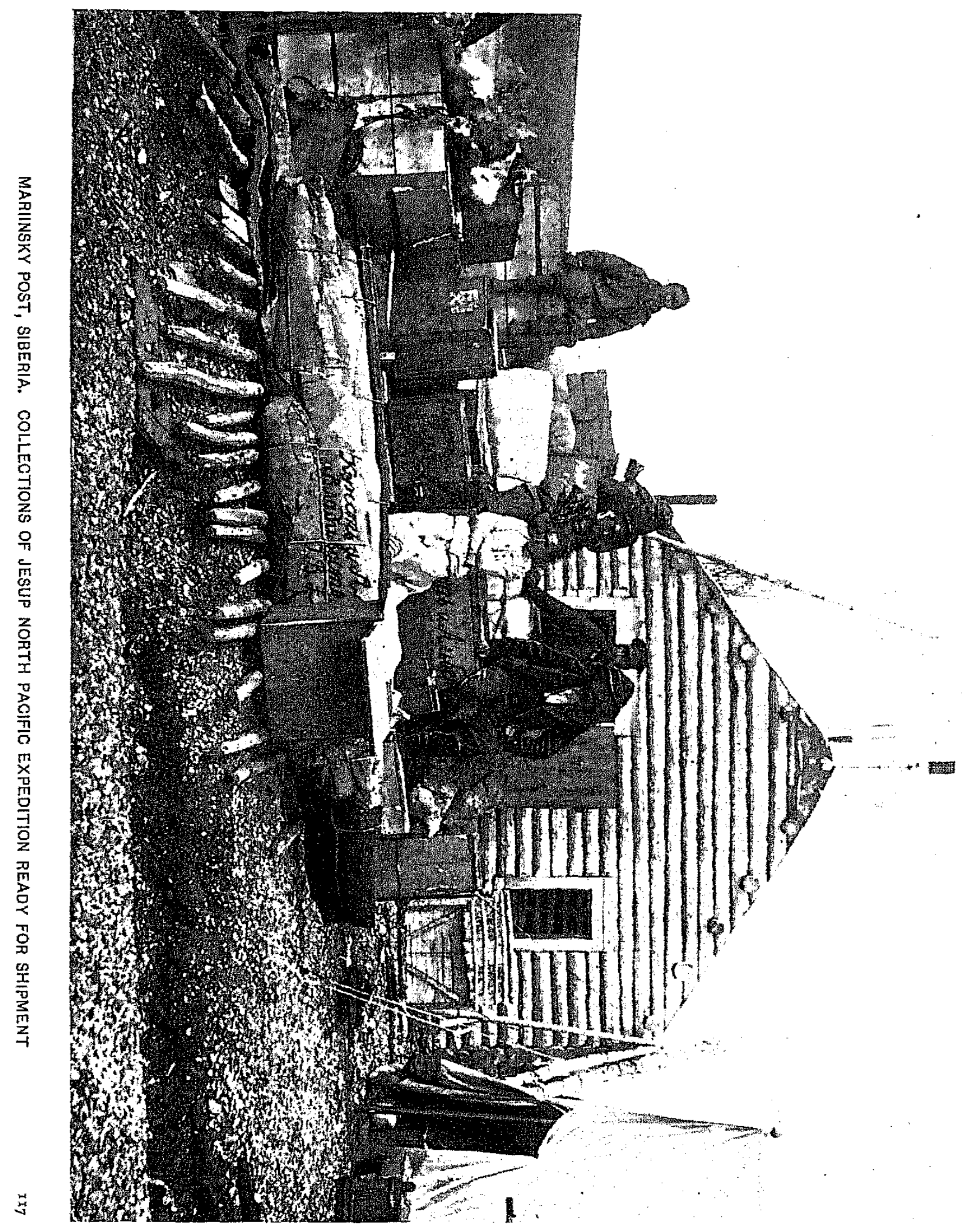




\section{THE AMERICAN MUSEUM JOURNAL}

Vol. V. Anthropology (not yet completed).

PART I. - Kwakiutl Texts. By Franz Boas and George Hunt. Pp. I-270. January, I902.

PART II. - Kwakiutl Texts (continued). Pp. 271-402. December, I902.

Vol. VII. Anthropology (not yet completed).

PART I. - The Decorative Art of the Amur Tribes. By Berthold Laufer. Pp. I-79, pll. i-xxxiii, and 24 text figures. January, 1902 .

ETHNOGRAPHICAL ALBUM.

Ethnographical Album of the North Pacific Coasts of America and Asia. Part I, pp. I-5, p11. I-28. August, I900.

Among those in preparation are:

Vol. IV, Part V. - The Lillooet of British Columbia. By James Teit.

Vol. VII, Part II. - The Chukchee. By Waldemar Bogoras.

Vol. VIJI, Part I. - The Haida of Queen Charlotte Islands, B. C. By John R. Swanton.

Ethnographical Album of the North Pacific Coasts of America and Asia. Part II.

\section{NEWS NOTES}

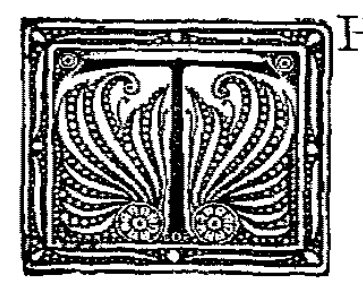

HE Department of Vertebrate Palæontology has recently received two very handsome gifts: the skull of the white rhinoceros of Africa from J. Pierpont Morgan, Esq.; and casts of the skull, brain cavity and foot of two species of Uintatherium, a cast of the skull and jaw of Brontops robustus and a cast of the skeleton of Anchisaurus, presented by the Yale University Museum through Professor Charles E. Beecher.

Professor J. E. Duerden, Honorary Curator of Colenterates, who has spent the past year as interim professor of biology 